\title{
AVALIAÇÃO ECONÔMICA DAS PERDAS PROVOCADAS PELA ÁREA DE EMPRÉSTIMO DA BARRAGEM DO RIO JUNDIAÍ - SP
}

\section{MARIA LETÍCIA DE SOUZA PARAÍSO \\ Engenheiro Agrônomo}

Orientador: Prof. Dr. Paulo Fernando Cidade de Araújo

Dissertação apresentada à Escola
Superior de Agricultura "Luiz de
Queiroz", da Universidade de São
Paulo, para obtenção do título de
Mestre em Agronomia, Área de
Concentração: Economia Agrária.

PIRACICABA

Estado de São Paulo - Brasil

Novembro - 1994 


\section{CATALOGAÇÃO NA PUBLICAÇÃO \\ DIVISÃO DE BIBLIOTECA E DOCUMENTAÇÃO - CAMPUS “LUIZ DE QUEIROZ”| USP \\ Paraiso, Maria Leticia de Souza \\ P241a Avaliação Econômica das perdas provocadas \\ pela área de empréstimo da Barragem do Rio \\ Jundiai-S.P.. Piracicaba, 1995. \\ 114 p.ilus.}

Diss. (Mestre)-ESALQ

Bibliografia

1.Recursos Naturais-Conservação 2.Meio Ambiente-Conservação. 3. Barragem do Rio Jundiaí

Aspectos Econômicos. I. Título II. Escola Superior de

Agricultura "Luiz de Queiroz", Piracicaba.

C.D.D. 333.715

333.714 


\title{
AVALIAÇĀO ECONÔMICA DAS PERDAS PROVOCADAS PELA ÁREA DE EMPRÉSTIMO DA BARRAGEM DO RIO JUNDIAÍ - SP
}

\author{
MARIA LETÍCIA DE SOUZA PARAÍSO
}

Aprovada em: 24/05/1995

Comissão Julgadora:

Prof. Dr. Paulo Fernando Cidade de Araújo - ESALQ/USP

Prof. Dr. Geraldo Sant'Ana de Camargo Barros - ESALQ/USP

Prof. Dr. Gerd Sparoveck - ESALQ/USP

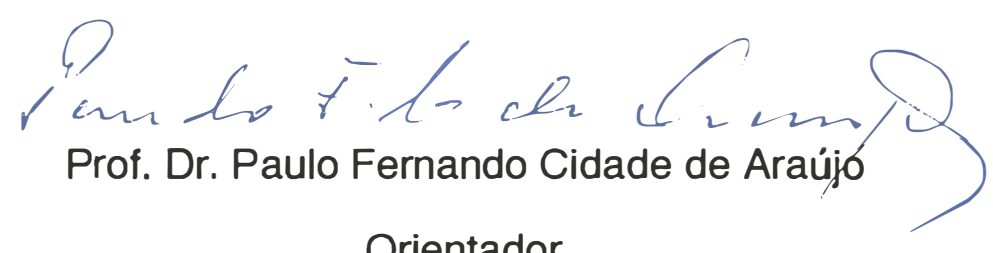

Orientador 

"If it took England the exploitation of half the globe to be what it is today, how many globes will it take India?"

\section{Gandhi}




\section{Agradecimentos}

Esse trabalho, relacionado diretamente ao uso dos recursos naturais, necessitou para sua execução da participação de muitas pessoas; que colaboraram com seus conhecimentos específicos ou com uma contribuição não menos importante, seu incentivo para que persistíssemos no trabalho. Para não faltar com nenhuma, deixando-as de citar, preferi agradecê-las espiritualmente; de coração agradeço à todas as pessoas que de qualquer modo me auxiliaram e neste item somente faço referência a razão principal e inspiradora do trabalho, o próprio meio ambiente e seus recursos naturais. 


\section{"Cântico das criaturas"}

\section{Altíssimo, Onipotente, Bom Senhor!}

Teus são o louvor, a glória, a honra e todas as tuas criaturas, especialmente o senhor irmão sol, que clareia o dia e com a sua luz nos ilumina. Ele é belo e radiante, com grande esplendor, de ti altíssimo, é a imagem.

Louvado seja meu Senhor, pela irmã lua, e pelas estrelas, que no céu formaste, claras, preciosas e belas. Louvado sejas, meu Senhor pelo irmão vento, pelo ar, pelas nuvens, pelo sereno e por todo o tempo com que dás sustento as tuas criaturas.

Louvado sejas meu Senhor, pela irmã água, útil e humilde, preciosa e casta. Louvado sejas, meu Senhor, pelo irmão fogo, com qual ilumina a noite. É belo, alegre, vigoroso e forte.

Louvado sejas meu Senhor, por nossa irmã terra, que nos sustenta e governa , produz frutos diversos, flores e ervas. Louvado sejas, meu Senhor pelos, que perdoam pelo teu amor, e suportam as enfermidades e as tribulações.

Louvai todos e bendizei ao meu Senhor, dá-lhe graças e servi-o com grande humildade. 



\section{SUMÁRIO}

Página

LISTA DE FIGURAS xiiil

LISTA DE TABELAS XV

RESUMO xvii

SUMMARY xix

1 - EMERGÊNCIA DO PROBLEMA E ABORDAGEM ECONÔMICA 01

2 - METODOLOGIAS DE AVALIAÇÃO ECONÔMICA DOS RECURSOS

NATURAIS 18

2.1 - Técnicas Baseadas em Preços de Mercado .24

2.2 - Técnicas Baseadas em Mercados Substitutos ou Hipotéticos .26

2.3 - Técnicas Baseadas em Pesquisa de Opinião ou Contingent Valuation

Method (CVM) 29

2.4 - Técnicas Baseadas em Custos Evitados ou Benefícios Perdidos 31

3 - CONTEXTO E METODOLOGIA 34

3.1 - O Problema. 35

3.2 - Contexto Histórico, Institucional e a Situação Geográfica da Barragem do Rio Jundiaí

3.3 - Barragens .

3.4 - Descrição da Construção da Barragem do Jundiaí. 44

3.5 - Cálculo da área, do Local de Estudo, Área de Empréstimo, 45 


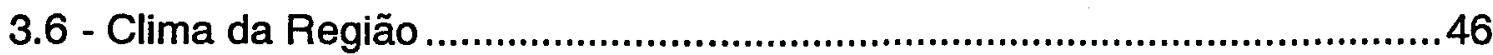

3.7 - Dados Fisicos da Barragem do Rio Jundiaí ............................................46

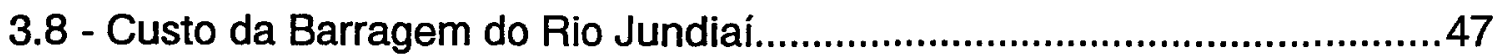

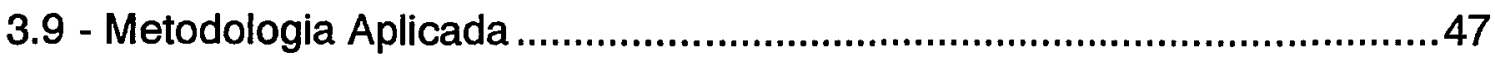

4 - APLICAÇÃO DA TÉCNICA DE AVALIAÇÃO ECONÔMICA

SELECIONADA PARA O CASO DE ÁREA DE EMPRÉSTIMO ..................51

4.1 - Aplicação das Técnicas de Avaliação de Recursos Naturais Selecionadas, na Área de Empréstimo abandonada do Rio Jundiai.........52

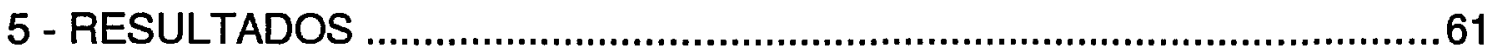

5.1 - Estimativa do Custo do Projeto de Recuperação da Área........................61

5.2 - Estimativa do Custo de Oportunidade da Utilização de Área de Empréstimo (130 ha), sem Posterior Recuperação............................64

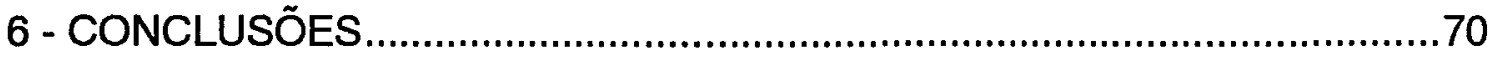

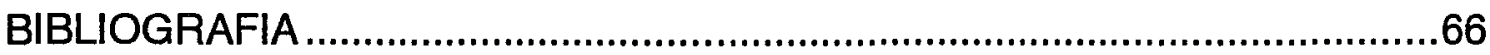

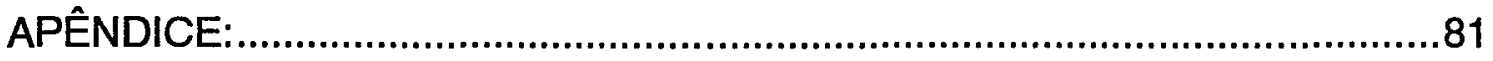

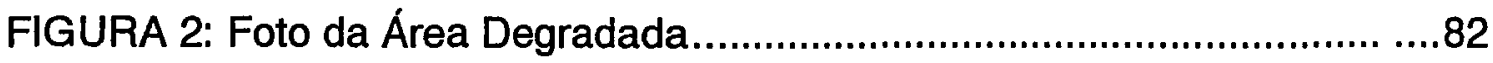

FIGURA 3: Localização da Bacia do Alto Tietê no Estado..............................84

FIGURA 4: Sistema Produtor da Região Metropolitana de S. P. em 1986.. ....86

FIGURA 4a: Evolução dos Sistemas Produtores de Água da R.M.S.P. até 2010 ....88

FIGURA 5: Represa do Rio Jundiaí, vista pelo Satélite LANDSAT-5..............90

FIGURA 6: Barragem de Concreto do Rio Jundiaí - Seções Principais ...... ....92

FIGURA 7: Índice Pluviométrico da Barragem do Rio Jundiaí .......................94 


\section{LISTA DE FIGURAS}

Página

FIGURA 1: SIMPLES MODELO TERMODINÂMICO DA ECONOMIA..................09

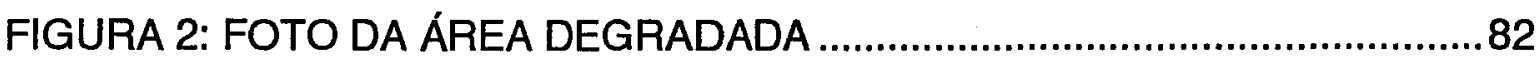

FIGURA 3: LOCALIZAÇÃO DA BACIA DO ALTO TIETÊ NO ESTADO.......... 84

FIGURA 4: SISTEMA PRODUTOR DA R.M.S.P. EM 1986 .......................... 86

FIGURA 4a: EVOLUÇÃO DOS SISTEMAS PRODUTORES DE ÁGUA

DA RMSP ATÉ 2010....................................................... 88

FIGURA 5: REPRESA DO RIO JUNDIAÍ, VISTA PELO SATÉLITE

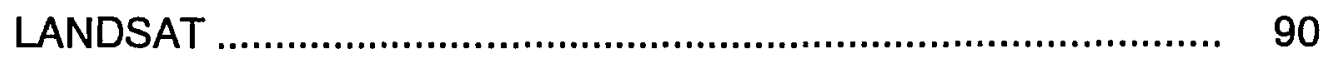

FIGURA 6: BARRAGEM DE CONCRETO DO RIO JUNDIAÍ -

SEÇÕES PRINCIPAIS......................................................... 92

FIGURA 7: ÍNDICE PLUVIOMÉTRICO DA BARRAGEM DO RIO JUNDIAÍ..... 94 





\title{
AVALIAÇÃo ECONÔMICA. DAS PERDAS PROVOCADAS PELA ÁREA DE EMPRÉSTIMO DA BARRAGEM DO RIO JUNDIAÍ - SP.
}

\author{
Autora: MARIA LETICIA DE SOUZA PARAISO \\ Orientador: PROF. DR. PAULO FERNANDO CIDADE DE ARAÚJO
}

\section{RESUMO}

A avaliação econômica de recursos naturais é muito importante como contribuição para tomada de decisão quanto à utilização dos recursos naturais. Hoje devido ao fato da ocupação antrópica atingir praticamente todo o globo e a humanidade possuir altos níveis de consumo dos recursos naturais, ou pelo menos almejar atingi-los, desde que esse é o modelo de sociedade que se busca atingir, acredita-se ser esse assunto determinante para o futuro da humanidade.

Esse tipo de avaliação possui muitas dificuldades; a própria tentativa de quantificar o valor dos recursos naturais é por si só uma avaliação subjetiva. Além do problema de muitos desses recursos não terem os seus direitos de propriedade estabelecidos, não possuírem mercado, seus efeitos atingirem muitas pessoas por diferentes períodos de tempo, e os mesmos ainda não podem ser determinados com precisão. A própria utilidade futura desses bens é incerta sendo que a análise a ser feita deveria ser de longo prazo. Por essas peculiaridades, algumas técnicas tem sido desenvolvidas, especialmente para avaliar esse tipo de recurso.

Algumas dessas técnicas são descritas no presente trabalho. Existem diversos trabalhos teóricos (em língua inglesa) sobre o assunto, mas faltam aplicações práticas. Assim, com essa finalidade optou-se por fazer um estudo de um caso restrito, em caráter exploratório; a avaliação econômica do dano monetário sofrido pela sociedade quando da utilização de uma área de empréstimo. Como uma prática comum em construções, foi utilizada a parte impermeável do solo para constituir o maciço da barragem, no caso da Barragem do Rio Jundiaí. No caso, não houve o mínimo trabalho que visasse a 
recuperação da área que fora degradada pela exploração e que se transformou em um local praticamente deserto. O valor monetário do dano ambiental foi calculado através de uma combinação de metodologias conhecidas e aplicadas conjuntamente nesse caso específico, em caráter exploratório. Primeiramente, obtendo-se o custo de reposição das funções ambientais daquele ecossistema degradado, a partir de um projeto de recuperação da mesma. O projeto feito levou em conta principalmente o estado atual da área e a viabilidade do projeto, não apenas agronomicamente, mas quanto ao seu custo também. Depois, foram calculados os benefícios que poderiam ter sido produzidos na área durante todo o período em que ela permanece sem gerá-los. Isto foi feito partindo-se do princípio de que um benefício não gerado é considerado economicamente perdido e este pode ser equivalente ao valor do bem. Assim usando-se uma situação hipotética calculou-se o valor monetário adicional que a área poderia ter produzido se tivesse sido explorada economicamente com a cultura agrícola Os dois valores obtidos são considerados o custo ou o dano causado à sociedade pela exploração da área de empréstimo. Isso ainda deve ser acrescido de alguns valores que não puderam ser estimados e, por isso, são apenas citados.

Essas estimativas foram feitas através dos métodos custo de reposição e do custo de oportunidade. Os cálculos mostram valores aproximados de US\$ 736 mil para o custo do projeto de recuperação das funções ambientais do ecossistema e US\$17,6 milhões para o valor que hipoteticamente poderia ter sido adicionado pelo ecossistema local no período em que ele esteve desabilitado o que não passa de seu custo de oportunidade respectivamente. Os resultados numéricos obtidos não são tão importantes quanto o simples estudo da metodologia aplicada. Estes devem ser de grande valia para progressos futuros nessa área, ao que tudo indica, muito necessários para a construção de uma sociedade sustentável. 


\section{ECONOMIC EVALUATION OF THE DAMAGE CAUSED BY THE BORROWED AREA OF THE JUNDIAI RIVER DAM - S.P.}

Adviser: PROF. DR. PAULO FERNANDO CIDADE DE ARAÚJO

\section{Summary}

The economic evaluation of natural resources is an important contribution to the decision making process of their utilization. The globe, in almost its totality, has an antropic occupation and so a very high consumption of natural resources. Those resources have peculiar characteristics, and are in general not marketable. For these reasons their evaluation tends to be very subjective. They also present problems related to market failure, property rights and off-site effects.It should be stated that much more research on this field is needed due to the scarcity of information and bibliography.It is important to mention that some new methodologies to measure and quantify monetary values referring to intangible environment benefits are being created. This is important because these benefits are frequently ignored or undervalued in common analysis. This dissertation presents a case study on this subject. It is related to the area that provided soil for the construction of the Jundiai Dam, located in São Paulo. At the international level, a large amount of theoretical tools was developed, but very little resulted feasible and possible of being applied to such a case. It also discusses the damage to society when the matter of a borrowed soil is removed and the ecological functions of the area aren't recovered. Therefore, the borrowed area is considered not adequately recovered. The methodology to evaluate, in monetary terms, the damage 
consists in estimating the cost for the replacement and its opportunity cost as well. The total sum of these values represent the actual damage to society. The results of this research 're US\$ 736 thousand to recover the ecological functions of the borrowed area, and US $\$ 17,6$ million as the opportunity cost of the area during a twenty year period of disqualificacion. 


\section{1 - EMERGÊNCIA DO PROBLEMA E ABORDAGEM ECONÔMICA}

O padrão de uso ótimo e eficiente dos recursos naturais como o ar, a terra e a água tornou-se grande preocupação mundial nas últimas décadas. Os problemas ambientais, ou como definem os economistas ecológicos, "efeitos indiretos de ações individuais sobre o bem-estar comum, estes resultantes dos processos de desenvolvimento da humanidade ou simplesmente do crescimento populacional e de suas conseqüências" - são extremamente complexos, suas inúmeras variáveis são interdependentes e de difícil explicitação.

Esses problemas envolvem uma multiplicidade de conhecimentos e formas de abordagem e, desse modo, necessitam de informações multidisciplinares para serem bem compreendidos. Entretanto, para se fazer uma análise geral, podem ser classificados por escala ou área de abrangência do impacto causado ao ambiente.

Primeiramente, apresentam-se os problemas realmente globais, isto é, aqueles que atingem toda a humanidade, nem sempre de modo equivalente, 
mas sem distinção. É certo, porém, que estes também causam impactos somente locais ou pontuais.

Nesta categoria, pode ser citado, o aquecimento global do planeta (elevação da temperatura média da atmosfera da Terra) devido ao aumento da concentração de $\left(\mathrm{CO}_{2}\right)$ e a possibilidade da ocorrência do "efeito estufa". Este é provocado pelo grande acúmulo de determinados gases na atmosfera (dióxido de carbono - $\mathrm{CO}_{2}$ - e o metano $-\mathrm{CH}_{4}$ ). Estes gases reagem formando uma película que funciona de maneira semelhante ao vidro de uma "estufa", dificultando que as irradiações de calor saiam da atmosfera da Terra e passem para o espaço. Com isso provocam concentração de gases e o aumento da temperatura média na Terra. Esse processo é resultante da crescente utilização de combustiveis fósseis e biomassa, afinal esses gases são produzidos pela queima de produtos orgânicos em geral (madeira, petróleo e derivados) ou pelas próprias funções digestivas dos animais. A respeito de problemas globais ver, por exemplo a publicação do Serviço Social do Comércio, Ecologia: Qualidade de Vida (1992), o livro Uma Terra, um Futuro (1992), todos eles posteriores a publicação da Comissão Mundial para o Meio Ambiente e Desenvolvimento "Nosso Futuro Comum" que ressaltou a importância desse tipo de abordagem e teve repercussão mundial. No assunto em questão tem-se que a elevação da temperatura média da Terra e outras mudanças climáticas possiveis de ocorrer podem ter conseqüências ainda imprevisíveis. Os estudos feitos não são conclusivos. Existe a possibilidade, controvertida, mas sobre a qual já existe estudo, de ocorrer degelo dos pólos provocando a elevação do nivel dos mares e a inundação de muitas cidades.

Outro exemplo é o buraco na camada de ozônio que recobre a Terra e que serve de proteção aos seus habitantes, evitando que os raios ultravioletas ultrapassem-na. Esses raios atingindo a Terra provocam, em altas doses, maior intensidade de ocorrência de câncer de pele e problemas de visão. Foi constatada a existência deste primeiramente no Pólo Sul e sabe-se que ele vem aumentando progressivamente com a destruição sempre crescente de móleculas de ozônio. Isso continuará ocorrendo mesmo que ocorra a total substituição dos clorofluorcabonetos,(C.F.C's), porque esses liberam átomos de cloro, que é o destruidor do ozônio e têm efeito cumulativo, 
pois são capazes de permanecer pôr anos na atmosfera. Sem essa camada, a vida de muitos organismos seria impossivel. Afirma-se que este buraco se formou em virtude da liberação de gás clorofluorcarboneto (usado principalmente em refrigeração e em produtos aerossóis) e óxido de nitrogênio desprendido de aviões e mísseis.

Além desses, outro problema ainda não muito percebido, mas que atinge a humanidade como um todo, é a destruição da biodiversidade. Ela pode ocorrer naturalmente, mas quase sempre é devida à intervenções antrópicas no ambiente natural. Os mais diversos motivos (explorações agrícolas, minerações, hidrelétricas, ocupação urbana e outras) originam a eliminação dos "habitats" de determinados animais e plantas, que ficam sem ambiente apropriado que thes ofereça condições de suporte à vida, a fim de que possam procriar, transmitir aos descendentes seus caracteres e, assim, participar da contínua e imprescindivel evolução das espécies no planeta.

Essa questão se agrava ainda mais quando são eliminados ecossistemas únicos, onde provavelmente viviam algumas espécies raras e que não possuem boa replicabilidade dentro da biodiversidade do planeta. Tal processo vem também se intensificando em virtude da erosão genética que a agricultura moderna (incremento da utilização do melhoramento genético de sementes, matrizes, cepas, clones) e a chamada revolução "verde" são responsáveis dentre outras coisas .

Outros importantes problemas ambientais globais, como a exaustão dos recursos minerais não-renováveis, podem ser mitigados pelo próprio funcionamento dos mecanismos de mercado. A escassez de recursos provoca a elevação de seus preços, desencadeando uma série de processos; com vistas a alcançar a vantagem econômica que existe com a exploração desse recurso, gerada pôr tal incremento no preço; como a descoberta de melhor tecnologia para uma extração mais eficiente, a crescente reciclagem industrial e a descoberta de novas jazidas e/ou substitutos para o recurso. Isso ocorre até que o custo marginal de produção do recurso em vantagem se iguale novamente ao preço de mercado, o que reduz os ganhos. Então ocorre novamente outro período de escassez do recurso, depois em conseqüência os 
preços se elevam, e assim por diante. Esses ciclos podem se repetir várias vezes e afastar muito o ponto de exaustão previsto para determinado recurso, mas ele não pode ser evitado, se a humanidade continuar com o mesmos paradigmas para vida e os padrões de consumo atuais.

Por outro lado, os recursos naturais considerados renováveis podem deixar de se recompor. Isso pode ocorrer, e inclusive já ocorre, quando, através das novas tecnologias, se atinge um nível de exploração dos recursos maior que sua capacidade de renovação. Grandes áreas de Floresta Tropical na Amazônia que foram destruídas para serem cultivadas e/ou exploradas com pastagens, mesmo depois de abandonada a sua exploração, não conseguem se recompor naturalmente, em um tempo de cinco anos, por exemplo. A exploração/exaustão dos recursos naturais é real e definitiva. A base dos recursos e o progresso tecnológico ilimitado.

Ademais, entende-se que a questão ecológica não é um modismo semelhante à crise energética iniciada nos anos 70 . A crise energética representou o prenúncio de uma questão mais global da qual também faz parte o aproveitamento dos recursos naturais (MARGULLIS, 1990).

Em segundo lugar, quanto à escala de impacto, há problemas de abrangência transnacional, isto é, os que podem afetar mais de um país, tais como a chuva ácida nos países desenvolvidos, os acidentes radioativos que causam danos em nações vizinhas ( Ex: o acidente nuclear de Chernobyl) e cursos d'água que atravessam países e transportando sedimentos e poluentes. Incluem-se ai, devido ao seu porte, os grandes aproveitamentos hidrelétricos, que exigem a formação de enormes reservatórios e o conseqüente alagamento e/ou a utilização como área de empréstimo ${ }^{1}$ de extensões. do território, antes ocupadas por lavouras, florestas ou outros usos (Ex: a construção da Hidrelétrica Itaipu-Binacional, no rio Paraná, destruiu as cataratas de Sete Quedas ). Esse tipo de empreendimento pode, geograficamente, atingir uma

\footnotetext{
${ }^{1}$ ÁREA DE EMPRÉSTIMo são as jazidas próximas às obras, formada de materiais a serem utilizados na construção. Estes materiais resumem-se em cascalho, areia, silte e argila, além de maciços rochosos de onde se extraem britas e outros materiais para enrocamento.
} 
região bem restrita, mas os impactos provocados podem ser muito grandes e seus efeitos se expandirem por outras regiões do entorno ou mesmo distantes.

Existem, ainda, os problemas regionais, provocados em geral pela contínua necessidade de ocupação de novas áreas do território, devido ao progressivo aumento populacional e aos altos padrões de consumo da humanidade. Estima-se que no ano 2000 a população mundial será de aproximadamente 7,5 bilhões de habitantes. Ainda parece distante que se chegue a estabilização, principalmente considerando-se os países mais populosos, como a China e a Índia. Portanto, o homem necessita ocupar cada vez mais espaços para habitar, plantar, criar, procriar, produzir, consumir e, inclusive, para morrer (ele precisa ser enterrado). Qualquer tipo de ocupação, ou mesmo, um simples adensamento de áreas já ocupadas, geram muitos impactos em toda uma região.

A ocupação predatória, visando somente benefícios imediatos ao homem, ocorre ainda, com muita frequência, principalmente nos países subdesenvolvidos. Isto por eles ainda possuirem grande parte das novas fronteiras a serem ocupadas, taxas de natalidade elevadas e, atualmente, serem os maiores possuidores dos recursos naturais que ainda existem na Terra. Entretanto, isso acontece, principalmente devido à dependência econômica destes, já que a maior parte da renda gerada por esses países vem da transformação dos seus recursos naturais em valores monetários.

Nesse sentido, para viabilização da ocupação antrópica, não deveriam ser considerarados somente critérios econômicos e de curto prazo, o que pode significar optar pela alternativa mais barata - de fato, não se pensa na autosustentabilidade dos ecossistemas - por isso ocorrem os desmatamentos, as erosões; os deslizamentos de terras, o assoreamento dos rios pela deposição de sedimentos, dejetos e efluentes não tratados que são encaminhados aos ecossistemas em níveis superiores à sua capacidade de absorção. Tudo isso contribui para o aumento da ocorrência de enchentes, a contaminação dos mananciais de água, danos à flora e à fauna. 
Todos esses problemas têm conseqüências que não podem ser tratadas isoladamente. Abrangem as mais variadas regiões geográficas, as mais diversas áreas do conhecimento e, assim, devem ser analisadas.

Certos problemas ambientais, contudo, podem e devem ser tratados localmente, como a poluição atmosférica (fontes fixas e móveis de poluição); deposição e transporte de dejetos químicos e esgotos não tratados; e dos locais para disposição adequada de resíduos sólidos nas cidades (aterros sanitários, lixões, incineradores, usinas de compostagens). Não se deve esquecer também dos problemas causados pela má ocupação do solo. Estes normalmente têm conseqüências menos abrangentes.

O fato de os problemas ambientais sempre afetarem mais de um indivíduo e terem efeitos além dos limites territoriais de suas ações imediatas é uma constatação muito importante no estudo dessa área. Esse é um dado indispensável que se acrescenta ao fato de que, quando o assunto é ambiente, se trabalha, em geral, com bens e serviços economicamente caracterizados como bens públicos. Segundo MUSGRAVE \& MUSGRAVE (1988), esses são bens para os quais os mecanismos de mercado não funcionam plenamente. Entretanto RANDALL (1987) afirma ser essa classificação sujeita a confusões. Assim ele prefere classificá-los segundo o tipo de falha de mercado que o bem apresenta. Dessa forma, ele adota os termos bens e serviços não-exclusivos e não-rivais ou res communis e res nullius.

Estes são não-exclusivos ou Res nullius quando é impossível excluir o consumo de um bem ou quando o custo de impedir uma pessoa de consumir um bem (custo de transação) é maior que o benefício obtido. Por exemplo, o ar ambiente, a defesa militar de um pais, a biodiversidade, a água nos rios, lagos e oceanos, espécies selvagens migratórias, ou até mesmo consequências deletérias, como epidemias, ou ainda aqueles problemas ambientais de impacto global ou regional citados anteriormente. A não-exclusividade dos bens envolve normalmente o que os economistas chamam de externalidades, isto é, a produção ou o consumo de um bem por determinada pessoa afeta uma outra involuntariamente. A pessoa afetada não necessariamente recebe por isso, nem a causadora do impacto é devidamente penalizada. 
Estes são não-rivais quando, uma vez produzidos, os bens ficam disponiveis a todos e o consumo de uma pessoa não afeta a quantidade disponivel para outras. Ou seja, a mesma quantidade dos bens encontra-se disponivel a todos e não ocorre interferência entre os indivíduos, quando eles estão usufruindo de um mesmo bem. Cada consumidor tem acesso à produção total do bem. Por exemplo, a quantidade do ar respirado por uma pessoa não afeta aquela efetivamente disponivel a outras pessoas. Essa qualidade é um atributo físico intrínseco ao bem e não um simples arranjo institucional. Impedir uma pessoa de usufruir o calor do sol, assim como outros bens ambientais, é praticamente impossivel.

Grande parte da literatura sobre o assunto estabelece as duas qualificações conjuntamente como necessárias para um bem ser considerado bem público puro, mas basicamente a não-rivalidade é a mais importante, pois em geral, é suficiente para tornar a exclusão indesejável (ineficiente) mesmo que exeqüivel. Em função da proximidade das duas análises será utilizado neste trabalho o termo mais usual, bem público, não deixando de ter presente a crítica do autor já citado, Randall.

Outro ponto importante a ser levantado nessa área de estudo é que as questões ambientais, devido à sua grande complexidade, precisam ser tratadas de forma multidisciplinar para que possam ser encontradas soluções. Considerando-se a perspectiva do direito, salienta-se a interface entre essas duas áreas do conhecimento. Sobre o assunto, FREITAS (1993) escreve que "a visão individualista não tem como sobreviver na época atual. Vivem-se momentos marcados por transformações radicais, pela urbanização que determinou o agrupamento de grandes contingentes populacionais". Segundo Cappeletti \& Garth ${ }^{2}$ citado por FREITAS (1993), "a concepção tradicional do processo civil não deixava espaço para a proteção dos interesses difusos. $O$ processo era visto apenas como um assunto entre duas partes, que se destinava à solução de uma controvérsia entre essas mesmas partes a respeito de seus próprios interesses individuais".

2 CAPPELLETTI, M \& GARTH, B. Acesso à justiça. Traduzido por Ellen Gracie Northfleet. Porto Alegre: Editor Sergio Fabris, 1988. p.49. 
Esse novo ramo do direito, relativo ao meio ambiente, também se depara com o problema da globalidade dos interesses atingidos e, por esse motivo, acrescenta à noção usual dos direitos individuais, a de interesses coletivos ou difusos.

Retornando a área econômica, observa-se que a economia convencional é esquematizada ao máximo em manuais de iniciação, o que facilita aprender certas propriedades essenciais da economia de mercado. Assim, as interdependências complexas da realidade são representadas como um fluxo circular de bens ou serviços entre firmas e consumidores ou unidades familiares. As firmas pagam salários aos trabalhadores, que compram os bens e serviços por elas produzidos. Os consumidores poupam dinheiro, que as firmas tomam emprestado para fazer mais investimentos e pelo qual pagam juros. Os gostos e preferências desses consumidores constituem forças dominantes e determinantes no mercado. e eles procuram maximizar essa satisfação sujeita a restrições técnicas e de renda. Os investimentos feitos vão para produção de mais bens e serviços, que os consumidores adquirirão com o incremento da sua renda, e assim por diante.

O fluxo descrito pode ser expandido com a adição de governo, exportação e importação, mas a estrutura básica é a mesma que foi apresentada. Todas essas relações econômicas complexas ocorrem inseridas no meio ambiente, que é fundamental para a sustentação da vida na Terra, onde, aliás, essas ocorrem. Os sistemas econômicos utilizam-se do capital natural, e possuem uma rede de inter-relações com ele. Isto tudo ocorre, apesar desta rede não estar definida no modelo. Contudo, essa interdependência é muitas vezes obscura, ambígua, intangível, não é fácil de se identificar claramente e muito menos de se mensurar.

Portanto, neste aspecto este trabalho tem intenção de ser uma contribuição. Ele planeja através de uma visão holística do ecossistema terrestre; integrar a atividade econômica e o ambiente e ainda, fazendo uso dos instrumentos da ciência econômica, avaliar monetáriamente os recursos naturais explorados por uma atividade antrópica necessária e comum, a construção de barragens. 
Exemplificando-se como ocorre essa integração e usando como referência o livro de JACOBS (1991), intitulado "The Green Economy"; verificase que o modelo econômico convencional descrito anteriormente, se pensado termodinâmicamente, é incompleto e não representa uma máquina-motor intermitente. Ele não mostra certos aspectos do fluxo econômico e abstrai completamente a existência dos recursos naturais. A matéria prima, que é consumida diretamente ou é um insumo na produção de outros produtos; ou os resíduos dos processos ocorridos. Segundo JACOBS (1991), a crise ambiental é também uma crise econômica. Em uma análise de curto prazo, têm-se o seguinte modelo termodinâmico simplificado da economia:

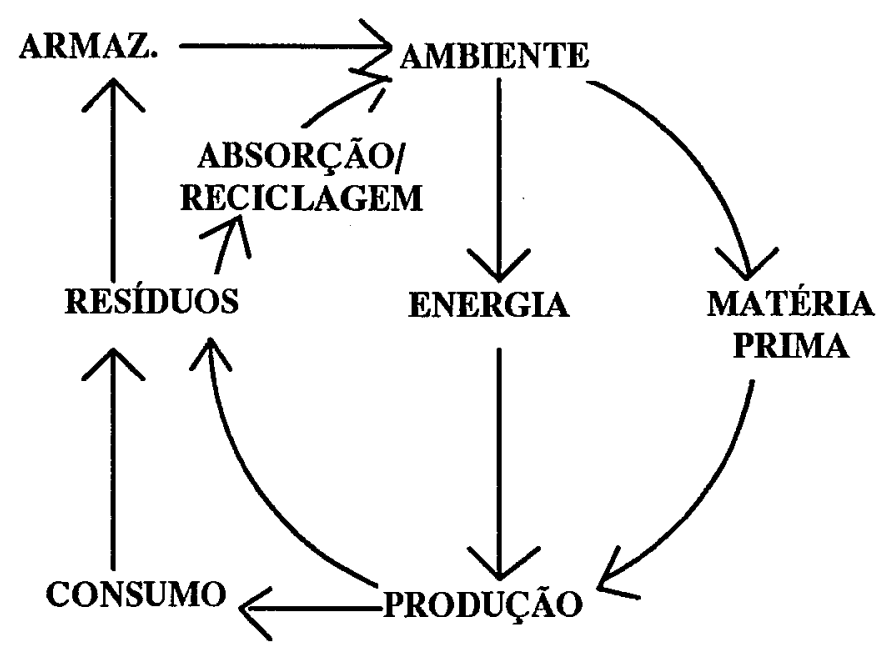

Fonte: JACOBS (1991)

FIGURA 1: Simples Modelo Termodinâmico da Economia 
Note que os retratos da economia - o descrito anteriormente e o apresentado na Figura 1 - são figuras "alegóricas" constituídas para enfatizar os contrastes entre as duas. Assim, percebe-se claramente que o modelo esquematizado acima, ao contrário do outro, representa um fluxo contínuo. Além das relações de trocas econômicas apresentadas também no outro, ele mostra a interação desses bens e serviços com o ambiente. Este fornece energia (energia fóssil, mineral, solar, nuclear) "combustível"; é o denominado capital natural, que permite a economia girar ininterruptamente. As plantas e os outros microorganismos, através da fotossíntese e também de outras reações, transformam a energia solar em matéria que outros seres vivos (situados depois delas na cadeia alimentar) usam para crescer e se desenvolver; fixam e promovem a ciclagem dos nutrientes. Estes, por sua vez, durante o seu ciclo de vida e após o seu fim (morte), produzem inúmeros residuos que são absorvidos e reciclados com 0 auxílio de organismos (assimiladores), os quais utilizam indiretamente a energia do sol.

Os recursos ou fatores de produção e os bens normalmente passam por diversas transformações durante o processo produtivo. Porém, por mais sofisticada que seja a tecnologia, elas não deixam de ter interrelações com o ambiente. E para esse devem retornar na forma de algum tipo de resíduo. Isso ocorre, mesmo que, através de processos como a reciclagem de produtos, eles retornem para os ciclos econômicos passando direto pela fase de resíduo. Ainda que ocorram várias reutilizações, por fim o produto acaba se transformando em um tipo de resíduo. O homem ainda não descobriu como criar a matéria prima totalmente artificial, uma vez que necessita sempre retirar algo da natureza para produzir bens, mesmo materiais conhecidos como material artificial. O ambiente, então, estará sempre prestando algum serviço à sociedade, ou fornecendo matéria-prima, e/ou absorvendo ou degradando seus produtos para que seus elementos possam retornar ao fluxo econômico. A situação se apresenta como foi mostrada na Figura 1.

É preciso, ainda, que existam áreas na Terra para que esses resíduos sejam depositados. Somente depois de promovida a completa degradação, que pode demorar até milhões de anos, esses bens deixam de ser resíduos, passando a ser novamente elementos nos processos em geral. Essa é uma 
ligação e, ao mesmo tempo, um dilema entre a economia e a ecologia. $\mathrm{O}$ homem através da sua inteligência desenvolveu tecnologias para facilitar muito a sua vida e incrementar a sua produção de bens e serviços, mas também acelerou o processo de utilização e degradação dos recursos naturais e, assim, a produção de resíduos.

No entanto, o homem não conseguiu avançar tanto no processo inverso (usar os recursos sem destruir e acelerar a reciclagem, absorção e degradação dos resíduos). Portanto, apesar de todo o desenvolvimento tecnológico da humanidade, um dos fatores que ainda é limitante ao seu desenvolvimento são os recursos naturais. A madeira produzida, atualmente, é normalmente limitada pelas florestas remanescentes e não pela capacidade das serrarias. A pesca é limitada pelas populações de peixes e não pelos barcos pesqueiros. $O$ petróleo cru, que é extraído, é limitado por seus depósitos e não pela capacidade de perfuração e bombeamento. Hoje, quando outros conflitos da humanidade já foram, de certa maneira, resolvidos, ainda não se conhece bem a capacidade de suporte dos ecossistemas da Terra. Sabe-se somente que em alguns ecossistemas ela vem sendo atingida, pois estes estão sendo destruídos. Por esta razão, aumenta muito a importância da questão da conservação dos recursos naturais neste fim de século.

O homem necessita conciliar a pressão social existente para incrementar seus padrões de consumo e bem-estar da sociedade, com a necessidade de se preservar o meio ambiente. No presente estudo, pretendese integrar a economia e a ecologia, mas com uma visão de longo prazo, inserindo uma perspectiva ambiental na primeira. Coloca-se o homem não mais como o centro de todas as ações no planeta, mas como um dos seres vivos (dos mais importantes) de todo ecossistema terrestre e dessa maneira procurar-se há atingir um desenvolvimento sustentado. Por um lado, buscase dar um valor monetário a um recurso natural e, com isso, pelo menos aparentemente, tentar inserir esse recurso na teoria marginalista (neoclássica), dando o preço correto aos bens. Essa abordagem poderia ser considerada estritamente neoclássica. Entretanto, ainda que avaliar monetariamente um recurso natural possa ter essa conotação, prefere-se considerar essa abordagem inserida nos objetivos da agenda de pesquisa do campo 
transdisciplinar emergente (COSTANZA, 1994) da disciplina economia ecológica.

Há que se considerar que os bens naturais (Terra) devem sofrer uma diferenciação para com o capital (VEIGA, 1990). Esta disciplina também considera ser importante atribuir valores econômicos a bens e serviços do ecossistema. Mas, diferentemente de outras, não inicia suas análises pela eficiência alocativa dos recursos, como os neoclássicos, mas sim pela restrição que the é imposta. No caso dos ecossistemas naturais, é a sua capacidade de suporte que estabelece a priori o grau de impacto que o ecossistema pode sofrer para permanecer sustentável. A economia ecológica, diferentemente da teoria neoclássica, não considera os recursos naturais e o capital como bens substitutos, mas sim como complementares. No entanto, também necessita para sua análise, como a teoria neoclássica, de valores para os recursos, no caso os naturais, comparáveis aos de mercado, o que se pretende obter no estudo.

Neste estudo será utilizada uma metodologia de valoração indireta para se estimar os benefícios que os recursos naturais do terreno em questão poderiam gerar para a sociedade como um todo, e não para alguns indivíduos isoladamente. Para se utilizar os métodos de valoração direta, seria necessário um completo conhecimento sobre o ecossistema local, o que torna dificil e onerosa sua aplicação. Neste caso, em particular, isto seria impossivel, visto que a área já estava totalmente degradada. Uma análise bem feita através destes métodos custa caro e necessita de muito recurso humano e material para ser realizada. Este trabalho pode ser considerado uma pesquisa inovadora, pois procura estimar o valor monetário do dano causado a um ecossistema, além de indicar o custo de reposição da dinâmica do ecossistema local pela implantação de um projeto de recuperação da área degradada e procurar avaliar o período de tempo em que esse terreno ficou estéril, sem praticamente nada produzir, nem ervas daninhas.

Não obstante os bens que poderiam ter sido produzidos na área de empréstimo (suporte de fauna e flora nativa; processos ecológicos, fixação e circulação de nutrientes, manutenção do fluxo hidrológico, formação do solo, 
aumento da biodiversidade genética, educação, pesquisa, recreação, turismo e valor de existência) ainda não serem completamente negociáveis em mercado, atribuíu-se valor monetário pelo fato de existir uma área que poderia estar somente cumprindo suas funções ambientais (independente do que existir nela), mas simplesmente deixou de fazer. Parte-se da premissa de que cada espécie, por mais desinteressante que possa parecer ao homem, sem utilidade aparente, tem um papel dentro dos ecossistemas , e esse papel poderá ser valorado em termos monetários e incorporado nas políticas públicas, nas contas nacionais dos países, nas políticas de decisão, enfim no cotidiano das pessoas. Os valores então atribuídos são comparáveis àqueles dos bens e serviços transacionados no mercado como bens econômicos. Reafirma-se o assunto citando-se VEIGA (1990); 'O primeiro passo para que a ciência econômica supere seu manifesto desprezo pela especificidade das coisas vivas poderá ser o reconhecimento de que o conjunto da atividade econômica constitue apenas uma das inúmeras dimensões de um complexo composto de seres humanos, que estão em contínua interação com recursos naturais, a maioria dos quais, por seu turno, constituída de seres vivos".

Após esse trabalho, será obtido um valor dos recursos naturais, mais objetivo, por ser em termos monetários. Alguns bens, muito difíceis de serem avaliados monetariamente, serão citados apenas qualitativamente, porque também devem ser levados em consideração quando da tomada de decisão. $O$ instrumental da economia convencional usado é o que se julga ser o mais adequado. Não se espera com essa abordagem captar o valor intrínseco do ambiente, uma das objeções quanto à valoração econômica ambiental feita pela maioria dos ambientalistas. Eles consideram que "o ambiente deve ser entendido como o lar espiritual da humanidade, não simplesmente como sua fonte de riqueza" (VIOLA, 1993).

Ao se fazer essa avaliação, não se está negando a existência desses valores; ao contrário, justamente estes são alguns dos valores que foram perdidos quando se optou pelo uso da área de empréstimo, que vão ser apenas citados no presente estudo, pela dificuldade de sua mensuração. No caso, a maneira usual que o homem econômico, visto pela microeconomia convencional como individualista e egoísta, costuma raciocinar para tomar suas 
decisões, foi empregada. Este deve indicar o provável caminho que a sociedade seguirá e, desse modo, fazendo-se avaliações objetivas, como ela costuma fazer, acredita-se poder mudar esse caminho. Para essa análise, considera-se o homem econômico lógico (GIANETTI, 1990), que costuma agir movido por interesses individuais e não como um ser social, a não ser que seus interesses sejam coincidentes. A premissa adotada também pode ser útil para explicar a grande diferença entre o discurso e uma legislação bastante avançada no Brasil e a realidade cotidiana dos brasileiros, em geral, com um comportamento individual extremamente predatório com relação ao meio ambiente. Por exemplo, observa-se mesmo entre os indivíduos de elevado nivel cultural, que se dizem ambientalistas, como é difícil a opção, em suas ações cotidianas, pelos critérios de eficiência energética, reciclagem de materiais, redução de consumo perdulário e participação voluntária em tarefas comunitárias de limpeza ambiental. A verdade é que a situação que se apresenta para um indivíduo ou empresa com relação à utilização dos recursos naturais, principalmente na cultura do brasileiro, é a de que os bens/recursos naturais - ar, água, solo, vegetação e animais selvagens - são simplesmente oferecidos ao homem. Ao nascer, ele os recebe e utiliza-os conforme sua vontade. Portanto, qualquer cobrança por sua utilização passa a ser considerada absurda, pois se estará cobrando por algo que um Ser Supremo deu aos homens juntamente com a vida.

Assim, torna-se importante aprimorar as técnicas de valoração monetária e aceitar o fato do homem não ser proprietário unico de todos recursos ambientais. Afinal, algo que pertence 'a todos habitantes da Terra consequentemente não pertence a ninguém, pelo menos no sentido da propriedade privada.

Neste trabalho, acredita-se ser possivel atingir o objetivo comum das correntes de pensamento: do movimento ambientalista profissional e da nova disciplina acadêmica Economia Ecológica. Segundo VIOLA (1993), o movimento ambientalista no Brasil também começa a ter uma visão menos estreita da problemática ambiental e está deixando de ser avesso às questões econômicas. Atualmente, contudo os ambientalistas não só apoiam as causas 
que visam a total preservação dos recursos, mas também preconizam o desenvolvimento sustentado e o uso racional dos recursos naturais.

No segundo capítulo, será feita uma descrição teórica dos métodos de valoração econômica de recursos naturais $e$ as principais limitações encontradas, isto é, "o estado da arte" desse assunto.

No terceiro capitulo, será apresentado o problema da avaliação econômica das perdas ambientais que ocorreram devido à escolha de determinada área para ser utilizada como área de empréstimo na construção da barragem do Rio Jundiaí. Apresentam-se a situação que existe de fato na área; a situação legal atualmente quanto ao uso e à degradação dos recursos naturais, o contexto histórico, geográfico e institucional do aproveitamento de recursos hídricos em São Paulo e dessa barragem em específico. Uma visão geral sobre a construção de barragens e explorações de áreas de empréstimos, bem como a descrição da construção dessa, a metodologia de avaliação a ser adotada, informações sobre o clima na região e dados físicos da barragem em estudo.

No capítulo quatro, faz-se um exercício de aplicação das técnicas de avaliação econômica selecionadas para o caso. Primeiramente, calcula-se o custo para reposição da dinâmica do ecossistema da área que foi degradada, através de um projeto de recuperação desta. Depois, calcula-se o custo de oportunidade da área, referente ao período em que, após a exploração e posterior degradação, ela ficou sem fornecer à sociedade os benefícios que esse ecossistema proveria. Todos esses valores são transformados na mesma unidade monetária e mesmo ponto no tempo. Posteriormente, é feita uma comparação com o custo monetário da construção da barragem. Além disso, esses valores devem ser acrescidos daqueles que foram citados só qualitativamente, os quais atualmente não poderiam ser recompostos nem estimados. Esses valores juntos correspondem ao valor monetário necessário para compensar a degradação desse recurso natural ou o valor do dano monetário imposto à sociedade. As conclusões obtidas com o presente trabalho são apresentadas no capítulo cinco. 
Espera-se que este trabalho contribua para a preservação ambiental. Utilizando-se ferramentas de avaliação econômica, obtenha-se informações que servirão como instrumento no processo decisório relativo ao uso dos recursos naturais, desde que se tenha consciência das suas limitações.

Muitas vezes, as politicas públicas não são implementadas em virtude de normalmente não se possuir argumentos técnicos ou evidências tangiveis dos beneficios sociais e ambientais resultantes do direcionamento de investimentos e incentivos para projetos que contemplem a variável ambiental e promovam o desenvolvimento sustentado. Os líderes precisam de argumentos mais fáceis de serem compreendidos. Não adianta falar em ética e moral. É preciso falar em valores monetários tangiveis. Ademais, as decisões de planejamento, que envolvem recursos naturais, só consideram normalmente os interesses da politica regional vigente. Esta não deixa de ter sua importância, mas argumentos econômicos objetivos, que considerem as interações com o meio ambiente, devem ser levados em consideração. Eles não devem ser considerados como absolutos, mas sim como elementos de um todo e assim, juntamente com outros fatores, poderão ser tomadas decisões mais acertadas quanto ao uso dos recursos naturais.

O presente trabalho será importante para induzir os agentes econômicos causadores de impactos ambientais a cumprir a legislação existente. É necessário, ainda, criar condições para a implementação de uma legislação mais eficiente, que vise não a simples preservação do meio ambiente, mas sobretudo ao desenvolvimento sustentado. $O$ assunto avaliação do dano ambiental necessita de muitos trabalhos práticos, mesmo que sejam simples aplicações das metodologias existentes. Segundo dados do Ministério Público, a maior parte das ações civis ambientais no Brasil fica parada na fase de avaliação do dano ambiental.

Além disso, deve-se acrescentar que no caso de bens públicos e interesses coletivos, é difícil integrar os processos sociais, econômicos e ecológicos numa mesma análise. Com este propósito a análise multi-objetiva ou multi-critério vem sendo aprimorada (MUNASINGHE, 1993). Entretanto é importante notar que não existem hoje, instituições suficientes e capazes para 
realizar todas as tarefas necessárias. Está ocorrendo uma progressiva disseminação da preocupação pública com a deterioração da qualidade ambiental e a sociedade vem também, se organizando nessa matéria. Estão surgindo continuamente agências federais, estaduais e municipais que tratam do meio ambiente. Atualmente, existem grupos e instituições científicas que realizam pesquisas sobre essa problemática, e dentro da própria universidade e dos institutos de pesquisa surgem grupos que abordam especificadamente a problemática ambiental de modo interdisciplinar. Estimula-se a criação de cursos de formação em "ciência ambiental"; também existem e surgem continuamente novas organizações não-governamentais (ONG) que tratam do assunto meio ambiente. Por exemplo, existiam mais de 700 mil organizações não-governamentais (FELDMAN, 1992) quando da realização da ECO-92, conferência realizada no Rio de Janeiro em julho de 1992. A legislação brasileira sobre meio ambiente, apesar de não ser um dos instrumentos mais eficazes contra a degradação dos recursos naturais, tem sido constantemente atualizada para melhor cumprir seu papel. No momento, o governo brasileiro criou uma comissão para elaborar um anteprojeto de Código Ambiental que poderá trazer grandes mudanças para a área.

Os problemas relativos ao ambiente não têm fronteiras. Precisam ser encontradas soluções globais, e essa é a tendência que, paulatinamente, vem prevalecendo nos documentos internacionais. Nesse sentido, todos os esforços locais são válidos para que possam ocorrer mudanças imprescindiveis. Estas devem atingir, assim, nível global para a preservação da vida no planeta. 


\section{2 - METODOLOGIAS DE AVALIAÇÃO ECONÔMICA DOS RECURSOS NATURAIS}

A avaliação econômica de recursos naturais, ou o processo de se dar valor monetário a bens e serviços ambientais, é essencial como parte de uma política de decisão e análise desses recursos que busque alcançar a sustentabilidade dos ecossistemas. É também importante, para se calcular o montante necessário ao ressarcimento à sociedade pelo dano ambiental sofrido pelo meio ambiente (na prática, isso significa calcular-se o valor do dano ambiental) ou para se justificar o montante do valor monetário dispendido na preservação destes. Para poder se cumprir esses objetivos, é necessário obter valores ambientais em termos monetários que reflitam os custos para reabilitação funcional desses ecossistemas. 
O valor econômico do meio ambiente tem sido objeto de muita controvérsia; em sintese, contudo, pode-se apresentar a seguinte expressão:

\begin{tabular}{|c|c|c|c|c|c|}
\hline $\begin{array}{c}\text { VALOR } \\
\text { ECONÔMICO } \\
\text { TOTAL }\end{array}$ & $\begin{aligned} & \text { VALOR } \\
= & \text { DE USO }\end{aligned}$ & + & $\begin{array}{c}\text { VALOR } \\
\text { DE } \\
\text { OPCÃO }\end{array}$ & + & $\begin{array}{l}\text { VALOR DE } \\
\text { EXISTÊNCIA }\end{array}$ \\
\hline
\end{tabular}

Fonte: MC NEELY (1992)

Valor de uso é aquele atribuído diretamente ao ambiente pelas pessoas que o usam realmente ou só usufruem dos recursos naturais, pagando ou não por isso, degradando-os ou não. Todos os seres do planeta, por mais insignificantes que sejam, por menor renda que possuam, usufruem de ao menos algum bem ambiental. Os elementos que constituem a Terra e seus seres vivos (carbono,hidrogênio,oxigênio em suas diferentes formas) estão interligados por processos químicos, físicos e biológicos. Pode-se relatar o fato de que a maior parte dos seres vivos inspira oxigênio, que se mantém em concentrações adequadas à respiração deles no planeta, graças a processos ambientais que ocorrem continuamente. Portanto, o ambiente tem valor de uso para qualquer um que habite a face da Terra. Qualquer ser estará usufruindo de um serviço ambiental, uma vez que inspira o ar, com oxigênio (mesmo que hoje este venha se tornando cada vez mais impuro, devido às muitas externalidades que o poluem) e devolve $\mathrm{CO}_{2}$. Valor de uso costuma ser dividido em valor de uso produto e valor de uso consumo. Os valores de uso consumo são aqueles dos bens consumidos, sem passar pelo mercado. $\mathrm{Na}$ África, o extrativismo (caça, colheita e pesca) fornece uma contribuição considerável para o sustento da população. A lenha é um importante combustível para muitas comunidades. Segundo PEARCE (1987), no Nepal, Tanzânia e Malawi, ela fornece $15 \%$ das necessidades primárias de energia. Esses bens, que não passam pelo mercado, também têm um valor de uso e podem ser contabilizados monetariamente como os de uso produtivo. 
Valor de Opção, por sua vez, é um valor indireto, atribuído ao ambiente com base na aversão das pessoas ao risco de perder os benefícios que este (ambiente) poderia ter proporcionado a elas ou mesmo aos seus herdeiros, às gerações futuras. Eventos imprevisiveis podem ocorrer (ambientais ou socioeconômicos) e a sociedade dá valor pelo quanto ela pode se prevenir desses riscos. No caso dos recursos genéticos, o valor de opção significa o quanto deseja-se pagar hoje para poder ter o direito sobre esses recursos no futuro. Assim, uma planta qualquer da Amazônia, ainda nem sequer classificada, poderia, em um futuro próximo, a descoberta como fonte do princípio ativo de um remédio que poderia ser a cura de uma grave doença que venha assolar a humanidade.

Valor de Existência é a parcela mais dificil de se conceituar, pois representa um valor atribuído simplesmente pelo fato de existirem certas qualidades no meio ambiente, independente delas possuirem valor de uso atual ou futuro. Assim, uma pessoa que nunca viu - nem tem intenção de ver um determinado animal, exótico ao seu ambiente pode extrair alguma utilidade pelo simples conhecimento da existência dele e também pode extrair utilidade simplesmente pela observação de uma bela paisagem natural, uma flor, uma cachoeira e outros. Isso é valido também, para o caso de animais em extinção e outros ativos ambientais que podem estar muito distantes do cotidiano dessas pessoas. Dispostas muitas vezes a pagar muito pela sua preservação. $\mathrm{Na}$ prática, isso pode ser confirmado pelo montante de donativos recebidos pelas grandes Organizações Não Governamentais, tais como a World Wildlife Foundation, Green Peace e outras, para a preservação de espécies exóticas e áreas distantes. Quando se fala em valor de existência, fala-se da dimensão ética. O sentido de dever do homem que toma esse tipo de atitude, diz que ele não deve desejar para a natureza aquilo que não deseja para si; a extinção. Por isso, coisas tão simples passam a ter valor. Inclusive, estão sendo desenvolvidos métodos para calcular este.

As metodologias a serem apresentadas procuram quantificar esses valores econômicos, embora, na maioria dos casos, não seja possivel avaliar separadamente as parcelas do valor mensurado. Existem diversas metodologias de obtenção dos valores dos bens. As que serão apresentadas 
tomam por base a valoração direta do bem, quando existe mercado para esse bem; quando não, baseiam-se na valoração indireta, em mercados substitutos ou hipotéticos, pesquisas de opinião, custos evitados ou benefícios perdidos devido às mudanças ambientais ocorridas. Todas essas formas deveriam apontar para valores semelhantes.

São necessários muitos exercícios de aplicação dessas técnicas, porque, apesar de muitas delas terem sido desenvolvidas nas últimas décadas e algum progresso ter sido obtido, a maior parte foi aplicada nos E.U.A. ou em economias também desenvolvidas. Além desses paises possuírem um elevado nivel de renda e, sem graves problemas distributivos, em geral eles não dependem muito da exploração de recursos naturais.

Segundo alguns economistas, dentre os quais MARGULIS (1991), VEIGA (1992) e DIXON (1991), as principais limitações na determinação de valores ambientais são:

- a própria tentativa de quantificar esses valores, uma vez que esta se avaliando o bem estar das pessoas através da utilidade extraída por elas, o que, por si só, é um conceito muito subjetivo;

- a inexistência de mercado para a maioria dos bens e serviços ambientais, o que se tenta resolver com a criação de mercados substitutos ou hipotéticos. Mas esse artifício, como qualquer mercado real, não consegue tratar os problemas distributivos; indivíduos que não participam do mercado por falta de condições econômicas ou por não terem ainda nascido (gerações futuras) ou, ainda, por morarem muito distante do centro de decisões, não podem influenciar o mercado. Alguns produtos até poderiam facilmente ser contabilizados, mas são usados diretamente, sem passar pelo mercado, como os produtos extraídos diretamente da floresta (palmito, látex, lenha, castanha do Pará, óleo de carnaúba);

- um grande problema ao abordar questões ambientais é a globalidade dos seus impactos, apesar de os efeitos mais intensos terem um raio de ação pequeno. Alguns efeitos se estendem muito além de sua vizinhança, tendo efeitos regionais e até globais; "off-site effects"; 
- outra grande dificuldade, segundo MARGULIS (1991), além das limitações dos métodos econômicos, é o próprio desconhecimento técnico dos efeitos ambientais, biológicos, químicos e sociais provocados pelo homem. Se fossem conhecidos todos, ou pelo menos a major parte, os efeitos da poluição das mais diversas fontes e suas inter-relações com o homem, a vegetação, os animais e materiais. Seria trabalhoso, mas possivel, estimar precisa e adequadamente as perdas e os custos envolvidos. Além dessa falta de informação, têm-se outros dois tipos de incertezas. Quanto ao potencial de uso de espécies conhecidas e desconhecidas da natureza e quanto às futuras demandas da humanidade. Como existem milhões de espécies, tanto animais como vegetais, desconhecidas ou pouco conhecidas pelo homem, pode-se supor que muitas ainda devam ser descobertas. Por outro lado, alguns recursos muito importantes hoje, não o foram no passado e pouco se sabe quanto ao seu uso futuro. Acontece isso com a maior fonte de energia para o homem nos dias de hoje,: o petróleo, um combustivel fóssil e, por isso, a médio prazo um recurso limitado. Hoje juntamente com o gás natural ele representa a maior fonte de energia consumida pela humanidade; mas isso só ocorreu neste século e após as crises do petróleo dos anos setenta houve o incremento das pesquisas de fontes alternativas de energia o que leva a pensar que essa situação não deva permanecer sempre assim;

- os impactos e/ou benefícios produzidos pelo meio ambiente ocorrem em prazos muito longos. A técnica econômica utilizada atualiza os valores que ocorrerão no futuro, através de uma taxa de desconto (taxa de juros) tornando esses valores muito reduzidos quando vistos no presente. Isso resulta em decisões ecologicamente insustentáveis. Este tipo de análise pode considerar mais eficiente o uso intensivo dos recursos naturais, levando-os à exaustão;

- os sistemas ecológicos são muito complexos e, assim, quando drasticamente destruídos, muitas vezes ocorre que sua reabilitação funcional torna-se muito difícil e portanto o seu estado de degradação irreversivel. Essa recuperação pode levar de alguns anos até séculos, ou pode até mesmo jamais ocorrer em sua plenitude. Portanto, deve-se ficar muito atento as decisões a serem tomadas quanto ao uso de uma área, a degradação provocada pode vir a ser irreversível. Um fator importante a ser observado quanto às restrições ao 
uso, é se tipo de ecossistema é raro ou ele se repete em outras áreas. Em qualquer dos casos devem ser tomadas todas as medidas possiveis para se mitigar o dano imposto à sociedade ao se alterar ou destruir um ecossistema.

-uma grande limitação, quem sabe a que cause maiores dificuldades, é a falta de competitividade no uso dos recursos naturais. Esses são em sua grande maioria, bens não rivais e não exclusivos. Desse modo, mesmo que sejam comercializados no mercado, eles não refletirão preços considerados economicamente eficientes. Pode-se citar o caso das belezas naturais que para serem protegidas precisam de um grande investimento em capital, mas para sua manutenção essa necessidade se torna bem menor. Como apreciar uma beleza natural é um bem não-rival, o consumo de um indivíduo não afeta a utilidade extraída por outro. É mais eficiente em termos econômicos, que um número maior de pessoas usufrua do bem, para isso seu preço deve se aproximar de zero. Além disso, por tradição a cobrança para se usufruir a maior parte desses bens é zero ou insignificante. Então não se pode avaliar o que as pessoas pagariam por tais bens. Assim, nestes casos, os mecanismos de mercado não levarão a uma oferta adequada de recursos naturais. Isso ocorre mesmo para bens passiveis de exclusão; como parques naturais, através do bloqueio de suas entradas e a caça, pela venda de licenças. Isso ocorre porque as taxas cobradas não cobrem todos os benefícios gerados pelos recursos naturais. Aqueles benefícios que se propagam para além do território diretamente atingido são apenas recebidos como as externalidades em geral, sem se cobrar por elas, uma vez que os indivíduos não os pediram. Assim, tendo em vista que os custos do estabelecimento destas áreas são arcados, em geral, por recursos do Tesouro Nacional dos paises onde se localizam as áreas a serem protegidas e seus benefícios são recebidos por todos os cidadãos (contribuintes ou não), e mesmo por quem não os deseja ou considera que esses não possuem valor algum. Desse modo a proteção dos recursos naturais pode colaborar também para melhor distribuição de riquezas.

Como visto, as limitações persistem, mas é preciso caminhar em direção ao aperfeiçoamento metodológico da valoração dos recursos naturais. Desse modo, apresenta-se a seguir, uma visão geral das metodologias conhecidas, com esse escopo. 


\section{1 - Técnicas Baseadas em Preços de Mercado}

As técnicas baseadas em preços de mercado avaliam os efeitos de mudanças na qualidade e quantidade da produção, que é trocada no mercado. Podem ser agrupadas da seguinte maneira:

\section{- Diferencial de Produtividade}

Procura-se observar as mudanças na produtividade ocasionadas pela mudança na utilização dos recursos naturais. É importante verificar somente o diferencial, a situação com e sem o contexto atual de utilização dos recursos. O desenvolvimento de um projeto pode afetar a produção de um bem qualquer, positiva ou negativamente. Como exemplo, um projeto de gerenciamento de solo, envolvendo medidas de conservação do mesmo pode levar a um incremento da produção agrícola, tornandoa produção maior do que seria sem o projeto. Desmatamentos provocam aumento da produção agrícola em um primeiro momento, no momento seguinte o que vem é o aumento na erosão do solo que, por seu turno, aumenta também a deposição de sedimentos nos rios e barragens, causando efeitos negativos secundários ou indiretos na produção agrícola (pela diminuição da fertilidade do solo), na produção de energia elétrica, no fornecimento de água para irrigação (assoreamento dos rios com diminuição do seu potencial hidroelétrico) e no aumento do alcance das cheias (diminuição da calha dos rios). Os efeitos de desmatamento é um dos casos que pode ser mensurado através do diferencial da produtividade. Com esta finalidade deve-se obter valores das produções, na situação anterior e posterior ao desmatamento.

Outro caso, é o dos custos ambientais da poluição das águas e manguezais, que agora já estão sendo reconhecidos. Em locais onde eles afetam a pesca a curto ou longo prazo, o valor da pesca pode ser estimado diretamente usando preços de mercado atual e comparando os com o valor da receita no passado. Um exemplo empírico da abordagem do diferencial de produtividade é o estudo de ANDERSON (1987), o qual mede os benefícios do reflorestamento na Nigéria. Estudos realizados ao norte da Nigéria mostram 
que cordões de contenção de erosão têm efeitos significativos nas áreas agrícolas, geralmente numa faixa de $10 \%$ a $30 \%$ superior, de diferencial de produtividade. Esse tipo de abordagem é usado freqüentemente em análises benefício/custo nas quais muitos benefícios da exploração dos recursos naturais podem ser mensurados, tal como feito em um estudo sobre conservação do solo em uma pequena bacia hidrográfica no Nepal (HUFSCHMIDT, 1983). A maior dificuldade dessa abordagem é reconhecer todos os efeitos indiretos relacionados à exploração e, assim, obter dados completos sobre a situação antes e depois da utilização dos recursos. No entanto, quando essa for uma atitude corriqueira a ser tomada para o monitoramento do dano ambiental, o Diferencial de Produtividade pode vir a ser uma técnica muito boa, pois, utiliza os produtos cuja produção foi afetada pela mudança e os valores de mercado desses bens produzidos, e assim tende a refletir a situação que realmente ocorre no local.

- Perda de Ganhos

Mudanças na qualidade ambiental têm efeitos significantes na saúde humana. Colocar preço na vida humana é um dos temas mais controversos na economia do meio ambiente. Mas isso, às vezes, se faz necessário, sobretudo quando efeitos ambientais negativos colocam em risco a vida humana.

Sabe-se que a vida humana tem um valor infinito, não havendo preço para ela no mercado. Mas, na prática, a sociedade indiretamente atribui valores finitos à vida e à saúde humana quando toma decisões sobre políticas e projetos que afetam a qualidade do ambiente, segurança ou saúde de populações. Cada grande obra construída usou indiretamente essa valoração da vida quando escolheu o nivel de segurança que teria a obra. Maiores gastos nas obras reduziriam o risco de perda de vidas. É aconselhável encarar essas dificeis avaliações, ao invés de negar sua existência. Pode-se mensurar a produção perdida com a morte ou doença de um trabalhador, ou os benefícios ou custos com os gastos com remédios e assistência médica e equipará-los aos investimentos necessários à melhoria da qualidade ambiental. 


\section{2 - Técnicas Baseadas em Mercados Substitutos ou Hipotéticos}

As técnicas descritas neste item também usam informações de mercado, mas de modo indireto. Como muitos bens e serviços ambientais não passam pelo mercado, usa-se esse artifício, procurando ou criando mercados similares (o mais próximo possivel) e tomando para análise os preços neles determinados. A lenha usada como combustível por habitantes que moram próximo às florestas pode ser avaliada em comparação a um outro combustível (gás e carvão por exemplo) que seria usado se não existisse lenha. Mas para um bem que hoje não tem preço, não se pode assumir que vá existir a mesma demanda existente por ele, quando esse bem tiver preço. Quanto mais adequado for o substituto do produto, mais precisão a análise terá; quando a substituição não for perfeita, poderão ser feitos ajustes.

\section{- Valor de Propriedade}

O valor e uma propriedade é dependente de uma série de atributos, dentre os quais se incluem tamanho, material de construção e características relativas à qualidade ambiental. O objetivo dessa metodologia é determinar os preços implícitos relativos as caracteristicas ambientais das propriedades. método tenta estimar um valor dos benefícios da qualidade ambiental ou estimar o custo de sua deterioração. Comparam-se preços de propriedades em locais similares, sendo uns afetados e outros não por fatores relativos ao ambiente, tais como poluição do ar, poluição sonora, trânsito, acesso e distância de parques e boa qualidade de água.

Para obter o valor desse diferencial, é preciso trabalhar com muitos dados, tabulá-los (é preciso estabelecer padrões), e muitas variáveis. Para evitar os problemas de viés na análise, é preciso ainda não se excluir quaisquer variáveis relevantes. É necessário, portanto, tomar os cuidados econométricos. Antes disso, porém, é preciso observar que a população (brasileira, por exemplo) ainda não possui uma demanda tão acentuada por qualidade ambiental. Os atributos que atualmente valorizam uma propriedade são "outros", pois ainda está se iniciando o processo de valorização do meio ambiente como um bem de qualidade de vida. Isso já é comum, só para as camadas sociais de alta renda. Esse fato só poderia ser confirmado se 
houvesse aplicação de testes empíricos, o que ainda não foi feito. Mas a tendência é a de que isso venha a ocorrer também no Brasil. Portanto, é fundamental o conhecimento de que, com a estimativa da relação entre os valores das propriedades e um indicador de qualidade ambiental, se possa inferir sobre o custo privado ou social do impacto.

\section{- Custo de Viagem}

Essa abordagem é muito usada nos paises industrializados para avaliar os beneficios gerados por atividades recreativas em áreas protegidas. Toma-se por base que os gastos individuais com os "custos de viagem" têm uma relação com o quanto os individuos valorizam determinado bem. Os indivíduos demostram o valor dos benefícios produzidos por esses, aumentando ou diminuindo a demanda por eles; portanto, mostram reações a um mercado real, não hipotético. Essa metodologia se baseia na teoria da demanda do consumidor, usando-se como padrão de medida o tempo despendido na atividade e o valor que esse possui para cada indivíduo. Assim, manter o quanto um indivíduo dispende para usufruir dos benefícios da área, será seu "custo de viagem". Para tanto, determina-se o tempo que o indivíduo dispende para usufruir da área (seu valor é calculado em termos monetários, pelas receitas perdidas, multiplicando o valor horário do seu trabalho pelo número de horas gastas na atividade recreativa somadas ao custo do transporte para ter acesso ao local. Ligando-se o mesmo tipo de dado, obtido para muitos individuos, chega-se à curva de demanda pelos benefícios gerados pela área, normalmente considerados intangiveis. Para obter bons resultados com essa aplicação, muitos detalhes devem ser observados, sobretudo o de como os indivíduos devem ser divididos por zona de origem e distância do local. Isso pode ser visto com mais detalhes em PEARCE (1983). A estimativa dessa curva de demanda envolve conhecimentos econométricos e o seu desconhecimento pode levar à obtenção de dados enviesados. Note que o valor dos beneficios gerados pela área não é a soma dos "custos de viagem". Estes, são usados apenas para se obter a curva de demanda pelo bem.

Trabalhos semelhantes são feitos para estudar a localização de empreendimentos comerciais os quais possuem grande inversão de capital. 
Assim, nestes casos o tipo de análise feita para instalação de um parque de diversão torna-se semelhante a de um parque natural. Para efeito de análise econômica privada do empreendimento, eles realmente possuem características comuns, porém são bens totalmente diferentes.

Outra restrição à utilização dessa técnica é que ela necessita de uma quantidade enorme de dados, que após coletados ainda precisam ser tabulados, o que encarece sua aplicação. Isto além de se ter pressuposições muito rígidas como se assumir que o único motivo para a viagem é usufruir dos benefícios do local. Assim, a técnica possui algumas restrições quanto à sua utilização, mas pode ser usada com sucesso em alguns casos específicos (inclusive vem sendo utilizada no caso de Parques Nacionais de alguns países).

\section{- Diferencial de Salário}

Esta abordagem se baseia nas relações de demanda no mercado de trabalho, (valor decrescente do produto marginal do fator) e na oferta de trabalho sujeita as variações determinadas pelas condições de vida e de trabalho. Assim, pressupõe-se ser necessário um alto salário para atrair trabalhadores para regiões poluídas ou trabalhar em ocupações de risco.

Como no caso do valor de propriedade, essa técnica deveria ser usada somente quando há condições de mercado de trabalho perfeitamente competitivas. Outro defeito dessa abordagem é que ela reflete uma avaliação privada dos riscos de saúde. Isso porque o diferencial de salário pago aos indivíduos pelo trabalho em condições insalubres é totalmente livre e pode ser despendido quando e onde se quiser. Assim, caso o individuo sofra os efeitos negativos advindos da insalubridade do ambiente, provavelmente ele se tornará um ônus para a sociedade. O valor pago como adicional de insalubridade deve ter sido consumido anteriormente, já que para um cidadão comum, qualquer valor obtido no presente é maior que no futuro. Além disso, a doença contraida pelo trabalhador pode ser contagiosa, causando efeitos indiretos e tornando-se um custo social elevado. 


\section{3 - Técnicas Baseadas em Pesquisa de Opinião ou "Contingente Valuation Method" (CVM)}

$\mathrm{Na}$ economia convencional, define-se valor como sendo a expressão das preferências individuais humanas, tomando-se as preferências conforme expressas pelos preços. $\mathrm{Na}$ falta das preferências reveladas através do mercado, os economistas procuram obter informações sobre as preferências dos consumidores propondo questionamentos diretos sobre o desejo de pagar e/ou o quanto eles gostariam de receber em troca do ressarcimento ou tolerância ao custo a eles imposto. É, pois, uma forma de abordagem semelhante a criação de mercados substitutos. Esse processo de levantamento, denominado "Contingent Valuation Method (CVM)", pode ser feito pela distribuição direta de questionários ou por técnicas experimentais, nas quais a pessoa responde a várias simulações em condições de laboratório. Cria-se todo um contexto artificial, o mais próximo possivel do mercado real, e submetem-se os entrevistados à situação criada. Com isso, extraem-se avaliações pessoais sobre o valor de um bem, quando ocorre aumento ou diminuição na quantidade demandada deste, mesmo que não exista mercado para o bem. Após criado o mercado hipotético, próximo da realidade e os entrevistados respondem quanto pagariam ou aceitariam em compensação para incorrer em algum custo se existisse a situação hipoteticamente criada. Conforme o tipo de situação, é uma metodologia que pode ser útil.

O Contingent Valuation Method pode ser utilizado para medir não só o valor de um bem (uma bela vista, melhoria na qualidade da água, uma área de vegetação natural), mas também o contexto institucional no qual ele vai ser provido e a forma como vai ser financiado. A maior qualidade da CVM é que ela, tecnicamente, pode ser usada para avaliar qualquer recurso do ambiente, inclusive bens considerados intangíveis. Em certas circunstâncias, pode ser o único método disponivel para estimar os benefícios ambientais, como algumas caracteristicas cênicas, ecológicas (beleza, ar puro, aréas protegidas), para os quais não há informações de mercado. É preciso que exista uma boa informação sobre a contribuição dos bens ambientais para os indivíduos para que eles possam fazer uma avaliação correta. Esse método possui muitos defeitos, por não incluir aspectos de longo prazo, excluir as futuras gerações 
de suas perguntas, além de alguns problemas na sua aplicação: perguntas formuladas no questionário (os entrevistados precisam estar familiarizados com o bem, para isso usa-se diversos artifícios), ponto de partida (valor sugerido) para se valorar o bem, veículo de cobrança do valor sugerido, hipótese artificialmente criada, tipo de amostragem escolhida e interpretação dos resultados. Mas para resolver esses problemas existem muitas técnicas encontradas na literatura sobre o assunto (PEARCE, 1989; HUFSCHIMDT, 1983). Por exemplo, foram publicados textos sobre como evitar o viés da aplicação do método e a respeito de técnicas que se utilizam de um tipo específico de abordagem.

Outro problema importante desse método diz respeito à renda dos entrevistados. Contudo, isso pode ser contornado através de métodos estatisticos de amostragem. Ademais, quando se avalia o desejo de pagar algo por um bem, o valor obtido pode ser normalmente menor do que o valor que se deseja para receber como compensação, por não poder usar o bem ou incorrer em custos devido à sua utilização. A literatura diverge muito sobre os motivos dessa diferença que a teoria econômica não explica. Portanto, são necessárias mais pesquisas sobre o assunto. Apesar dessas restrições, esse método vem sendo muito aplicado nos paises em desenvolvimento, a fim de se avaliar a qualidade da oferta de água potável e de serviços de eletricidade. Realizou-se recentemente no Brasil, em São Paulo, uma pesquisa sobre as condições ambientais urbanas que questionou os moradores da cidade (amostragem estatística) com perguntas utilizando esse método, cujos resultados deverão ser publicados brevemente em. livro. Essa pesquisa, foi financiada pelo Stockolm Environment Institute, da Suécia, realizada pelo Centro de Estudos de Cultura Contemporânea, e coordenada pelo Professor Pedro Jacobi.

PEARCE e MARKANDYA (1989), comparando a técnica CVM com um método baseado em preços de mercado, encontraram uma grande superposição entre os dois. Existem muitos outros resultados positivos que dão a segurança de que um CVM rigorosamente aplicado pode não ser preciso quanto à ordem de grandeza dos valores obtidos, mas pode ser suficiente para 
escolher, entre projetos alternativos o mais adequado, considerando as variáveis ambientais.

\section{4 - Técnicas Baseadas em Custos Evitados ou Benefícios Perdidos}

Às vezes, é impossivel estimar os beneficios do melhoramento ou proteção da qualidade do ambiente, porque não existem informações sobre eles. Muitas vezes, é mais fácil estimar os custos impostos a uma área quando são explorados seus recursos naturais, desde que mantido o seu uso. Assim, os custos impostos podem ser considerados como beneficios, se olhados por outro ângulo. Um custo que foi evitado pode ser visto como um benefício. Esses custos ou benefícios reais (ou potenciais) são, então, calculados através de preços de mercado. Essa é uma técnica muito útil, principalmente porque os benefícios gerados pelos recursos naturais geralmente são muito difíceis de serem expressos em termos monetários. Mas através dos benefícios perdidos de um projeto de desenvolvimento ou de sua reformulação, isso se torna muito mais fácil. Em alguns casos, em que a área já foi ocupada, só é possivel encontrar os benefícios perdidos calculando-se o custo da reposição desses benefícios ambientais que teriam sido ou devem ser destruídos pela nova utilização dos recursos naturais.

\section{- Gastos Preventivos}

Quando se causa um impacto ao meio ambiente, podem-se tomar medidas que diminuam esses impactos. As medidas tomadas para mitigar esses impactos são geralmente menores que o valor do dano causado porque, segundo a teoria neoclássica, só se incorrerá em custos para evitar o dano enquanto este for maior ou igual ao valor gasto.

\section{- Custo de Reposição}

Esta abordagem é mais que um método. Ela pode ser considerada um conceito a se utilizar em vários métodos. Estima os custos incorridos para se repor um bem ou serviço ambiental. Essa avaliação não é uma medida para se 
evitar o dano, primeiro porque o custo do dano pode ser maior ou menor que o custo de reposição. Entretanto, é uma técnica apropriada desde que exista uma boa relação com o bem a ser restaurado e não exista como avaliar diretamente os bens existentes, como é o caso de áreas de empréstimo para construção de barragens que foram degradadas e abandonadas. A metodologia do custo de reposição tem sido aplicada para estimar os beneficios das medidas de prevenção à erosão, calculando-se o valor dos nutrientes necessários para repor aqueles que foram perdidos com a erosão do solo. Outro exemplo de aplicação é calcular o custo de uma criação artificial de alevinos, para se avaliar o benefício dos manguezais que serão destruídos por um projeto. Isso porque os manguezais servem como "berçários" para os peixes e, se destruídos, será perdida essa produção.

\section{- Projeto Sombra}

Quando se avalia um projeto que tem um impacto negativo no ambiente, sua abordagem pode envolver o desenvolvimento de um ou mais "projetos sombra", os quais devem suprir o ambiente daqueles recursos que serão perdidos com o desenvolvimento do projeto principal. Essa abordagem é, em essência, a mesma do custo de reposição. Vem sendo mencionada de modo crescente, como caminho possivel para o desenvolvimento sustentado, pelo menos em nível teórico. Dentro das premissas da economia ecológica, deve-se ter preocupação primeiramente com os ativos ambientais "críticos", que estão em risco. Esse é o conceito de sustentabilidade que se tem quando se assume que é impossivel deixar o capital natural intacto, mas que existe um limite para a capacidade de suporte do ambiente.

\section{- Custo de Oportunidade}

Essa técnica, ao invés de tentar medir os benefícios gerados por determinada apropriação de recursos, tenta medir as receitas que foram perdidas em um uso alternativo. Deve-se comparar o valor obtido diretamente com o do melhor uso alternativo para a área em questão. Os benefícios ambientais usualmente são considerados maiores que a simples receita obtida pelo uso dos recursos, devido à seus efeitos impactantes serem tão abrangentes, suas interrelações não conhecidas por completo e sua 
mensuração direta ainda muito dificil. Portanto esse dado é considerado suficiente como referência para a avaliação do bem.

\section{- Análise de Custo Efetivo (Effective Cost Analysis)}

Essa técnica é uma alternativa quando, realmente, é muito difícil a avaliação do bem. O importante é buscar atingir certo objetivo, que pode ser reduzido à simples obtenção de determinado nível de benefícios gerados pelos recursos naturais. Essa metodologia envolve um objetivo a ser atingido, a determinação dos custos de vários caminhos alternativos e a escolha daquele de menor custo. O primeiro passo para esse tipo de análise é decidir o alvo a ser atingido; exemplo o nivel máximo de poluição do ar, um certo nivel de qualidade da água, a população mínima de certas espécies. O objetivo a ser atingido deve ser escolhido apropriadamente. Uma vez estabelecido o objetivo, deve-se examinar as diversas maneiras de atingí-lo. Os custos das alternativas são calculados e escolhe-se a de menor custo. Essa metodologia é útil para guiar políticas nacionais e a tomada de decisões sobre o uso dos recursos naturais.

Essa rápida revisão geral sobre as técnicas de valoração ambiental não pretende esgotar o assunto, mas somente apresentar, de modo simples, as técnicas existentes ("o estado da arte"). Em função disso, será escolhida a metodologia a ser usada no presente trabalho. 


\section{3 - CONTEXTO E METODOLOGIA}

Neste estudo de caso restringe-se o assunto a ser abordado a áreas de empréstimo em barragens, mas assim mesmo, ele não deixa de ser uma orientação para os futuros trabalhos a serem realizados na área de recursos naturais, uma vez que analisa a aplicação de uma metodologia , a adequação ou não de algumas técnicas de avaliação econômica de recursos naturais e demonstra a necessidade de pesquisa experimental em economia ecológica. Primordialmente, será uma contribuição para aplicação de metodologias de avaliação econômica de recursos naturais. Portanto, é um trabalho difícil e sujeito a problemas técnicos e mesmo conceituais. Mas, como foi dito por MUNASINGHE \& LUTZ (1991), "a maior necessidade não é por mais teorias ou técnicas, mas por aplicação da metodologia existente na abordagem de problemas concretos, particularmente nos países em desenvolvimento". 


\section{1 - O Problema}

O Brasil, para suprir o crescente consumo de energia elétrica, está intensificando a exploração de seus recursos hídricos. Com esse objetivo vem planejando, construindo, operando e, conseqüentemente, degradando inúmeras áreas. A construção de uma barragem tem trazido muitos efeitos positivos, tais como: geração de energia hidrelétrica, fornecimento de água para múltiplos usos (abastecimento, irrigação), regulagem das cheias, diluição de esgotos, produção pesqueira e lazer.

Por outro lado, a construção de barragens em rios causa impactos ambientais negativos, em alto grau, tais como:

- modificações climáticas (incluindo temperatura, umidade, velocidade dos ventos);

- deslocamento ou perda da fauna e da flora, pela destruição de "habitats";

- inundação de jazidas minerais e de terras férteis;

- degradação pelo uso de áreas empréstimo na construção do maciço da barragem;

- impactos sociais não só pela inundação de povoados, mas também pela destruição ou modificação de sua estrutura de suporte econômico-social.

Será apresentada, a seguir, a valoração econômica das perdas ambientais provocadas pela opção de se usar determinada área de terra por empréstimo na construção da Barragem do Rio Jundiaí. Não se trata de uma análise custo/ benefício completa do empreendimento. No caso, vai ser avaliada somente a degradação de um terreno, aproximadamente 130 ha, que continua até hoje totalmente exposto, onde inclusive nem plantas daninhas nasceram. O terreno, localizado junto à Barragem do Rio Jundiaí, permanece sem cobertura vegetal, desde que se iniciaram as obras em 1977. 
A situação de degradação da área pode ser observada nas fotos que foram tiradas em 1993 no local, as quais estão apresentadas na Figura 2. Hoje, esse fato dificilmente ocorreria, pelo menos no grau de degradação verificado. Por um lado, porque existe a obrigatoriedade da apresentação do Estudo de Impacto Ambiental (EIA-RIMA) para licenciar a construção de obras potencialmente impactantes; por outro, as empresas que executam esses empreendimentos não se arriscam mais a provocar tais danos ambientais, sabendo que a sociedade é, pelo menos em parte, consciente e atenta para protestar contra agressões ao meio ambiente.

A sociedade tem funcionado como eficiente fiscalizadora em muitos países. Além disso, hoje existe legislação para coibir essas atitudes, inclusive a própria população pode tomá-las através das "ações civis públicas". Analisando-se através da visão econômica neoclássica da eficiência alocativa dos recursos, pelo ângulo visto da sociedade como um todo. Esses empreendimentos não deixam de ser, na maioria dos casos, exemplos de má alocação de recursos naturais. Os benefícios perdidos são bens públicos, a maior parte não comercializáveis, mas deveriam ser tratados como bens escassos, como realmente o são.

A luta contra a degradação do meio ambiente não se pode confinar somente em instrumentos do direito, muito menos do direito privado, que reflete uma lógica que prevê apenas a tutela de interesses individuais, e não dos interesses coletivos. É preciso considerar que a legislação pertinente às áreas degradadas tem evoluido muito. Apresentam-se a seguir, em ordem cronológica, fatos jurídicos que bem demonstram isso.

- Lei $n^{\circ} 6.938 / 81$, que em seu artigo $2^{\circ}$, obriga a recuperação dos sítios degradados.

- Resolução CONAMA 001/86 referindo-se à recuperação de área degradada pela mineração, através de medidas atenuantes.

- artigo 225 da Constituição Federal de 1988, que determina a recuperação do meio ambiente degradado pela exploração de 
recursos minerais, de acordo com a solução técnica exigida por órgão público competente.

- Decreto-Lei no 97.632/ 89, que regulamenta a Lei Federal no 6.938/ 81, obrigando a recuperação da área degradada como parte do Relatório de Impacto Ambiental, R.I.M.A...

Na prática, essa legislação não vem mostrando resultados significativos. Por isso, há mais um motivo para que a análise econômica enfatize a realização de pesquisa nessa área. Apresentam-se, a seguir, o contexto histórico, institucional e geográfico bem como os objetivos de realização da Barragem do Rio Jundiaí.

\section{2 - Contexto Histórico, Institucional e a Situação Geográfica da Barragem do Rio Jundiaí}

A Barragem do Rio Jundiaí faz parte do conjunto de obras que compõe o "Subsistema Alto Tietê", proposto no Plano Diretor de Obras, denominado "Desenvolvimento Global dos Recursos Hídricos das Bacias do Alto Tietê e Cubatão, elaborado em 1967 pelo Departamento de Águas e Energia Elétrica DAEE, através do Convênio HIBRACE.

Esse plano, embora de bem antigo, contemplava a Grande São Paulo do ano 2000, apesar de suas projeções populacionais não terem se confirmado completamente. É esse estudo que norteia até hoje, com poucas alterações, os planos para aproveitamento dos recursos hídricos para uso múltiplo no Estado de São Paulo. Algumas das barragens projetadas, ainda se encontram em fase de implantação (barragem de Biritiba); outras ainda estão em projeto e sendo reestudados (Itapanhaú e Itatinga). É certo que o crescimento econômico e populacional das décadas de 70 e 80 até o presente, exacerbou os conflitos, em particular quanto ao uso e ao aproveitamento da água. 
A demanda por água potável cada vez maior, as disponibilidades hídricas aquém das necessidades, os esgotos sanitários sem tratamento compatível com os acréscimos gerados e o agravamento das inundações caracterizam esse periodo.

Entretanto, fruto desse período são as Leis Estaduais $n^{\circ} 898 / 75$ e $n^{\circ}$ 1.172 / 76 de Proteção aos Mananciais da Região Metropolitana de São Paulo. Os resultados do Censo realizado pela Fundação IBGE em 1991, porém, revelaram a reversão das tendências até então observadas. Os saldos migratórios são negativos, sobretudo na Grande São Paulo, e os seus reflexos nas projeções populacionais e nas demandas de água precisam, portanto, serem reavaliados. Nessa conjuntura emerge a urgência da aprovação do "Plano Estadual de Recursos Hídricos". Este destaca a necessidade de um Sistema Integrado de Gerenciamento de Recursos Hídricos , o qual foi instituído pela Lei Estadual $n^{\circ} 7.663$ / 12-91 que toma por base os Planos de Bacias Hidrográficas, e cujas ações estão em andamento.

Conforme a Divisão Hidrográfica aprovada pelo Conselho Estadual de Recursos Hídricos (reunião de 25/11/1993 - Decreto $n^{\circ} 38.455$, de 21/3/1994), a bacia do rio Jundiaí, onde se localiza a área de empréstimo em estudo, faz parte da Bacia do Alto Tietê. Esta se compõe de trinta e quatro municipios, dentre eles Mogi das Cruzes, Salesópolis e São Paulo (ver Figura 3). Na Figura 4 observa-se, como se comportavam os sistemas produtores da Região Metropolitana de São Paulo em 1989. Se com o novo "Plano Estadual de Recursos Hídricos" não ocorrerem alterações, estes sistemas evoluiriam, chegando em 2010 conforme foi previsto e se apresenta na Figura 4a.

A área em estudo localiza-se dentro da região abrangida pela Lei de Proteção aos Mananciais e, para isso, é importante conhecer-se, de maneira geral, essa legislação.

Ela estabeleceu e denominou alguns cursos de água a serem protegidos, dentre eles o Rio Jundiaí, no Município de Mogi das Cruzes. Estabeleceu, também, algumas normas para a exploração dessas áreas, as quais compreendem restrições à deposição de lixo, às redes de água e esgoto 
na referida região, às obras de movimento de terra, ao tamanho do lote, as práticas agrícolas como o uso de agrotóxicos.

Como foi dito anteriormente, Algumas barragens do Sistema Alto Tietê ainda não foram concluidas (Biritiba), e outras ainda estão em projeto (Itatinga, Itapanhaú, Paraitinga), mas todas deverão ser reavaliadas.

As barragens que formam o citado Sistema Alto Tietê são barragens de acumulação (de água), isto é, não têm função de gerar energia e, assim, não são citadas na Resolução CONAMA 01/86, que exemplifica os empreendimentos que, a princípio, já necessitam de estudo de análise de impacto ambiental para seu licenciamento. Observando-as hoje, simplesmente pelo seu porte, essas barragens necessitariam de tal estudo para serem licenciadas. Elas estão sendo analisadas, quanto ao seu impacto, pelo Departamento de Análise de Impacto Ambiental - DAIA, da Secretaria do Meio Ambiente do Estado de São Paulo. Esse órgão, ao ser solicitado para licenciar os novos empreendimentos do Sistema Alto Tietê (barragem do Biritiba) julgou necessário que o complexo fosse analisado como um todo e, depois, cada barragem do mencionado sistema também o seria isoladamente. Por essa razão, o órgão empreendedor já vem tomando as medidas cabíveis para ressarcir a sociedade do dano que lhe foi imposto.

\subsection{2 - Localização}

O distrito de Jundiapeba, Municipio de Mogi das Cruzes, foi o local escolhido para a implantação da Barragem do Rio Jundiaí. O acesso é feito utilizando-se a estrada municipal que liga Mogi das Cruzes ao bairro de Arueiras. Saindo de Jundiapeba, pode-se também utilizar a estrada em direção a Varinhas, e ao $7,8 \mathrm{~km}$ toma-se a estrada para o bairro de Arueiras.

\subsection{3 - Objetivos}

A Barragem do Jundiai, interligada com a barragem de Taiaçupeba, forma um conjunto pertencente ao "Sistema Produtor Alto Tietê", que tem como objetivo o fornecimento de águas com padrão de qualidade suficiente para, com tratamento adequado (a água se destina a Estação de Tratamento do Alto 
Tietê, da SABESP), serem utilizadas no abastecimento da Área Metropolitana de São Paulo (fornecimento conjunto de uma vazão regularizada de $5 \mathrm{~m} \% \mathrm{~s}$ ).

O primeiro objetivo dessa barragem foi regularizar a vazão do rio Jundiai, para controle de enchentes e prevenção de inundações em áreas ribeirinhas. Buscou-se, ainda, a manutenção de diluição suficiente, durante todo ano (inclusive na vazante do rio), para assimilação dos resíduos líquidos, urbanos e industriais (assimilação de efluentes) jogados nos rios que formam a bacia do Alto Tietê. Essa função de uma barragem, também é difícil de ser avaliada monetariamente, mas deve ser considerada, pois é um serviço ambiental da maior valia, prestado pela natureza (recepção de dejetos). Como se referem Maler e Wyzga ${ }^{3}$, citados por MAY \& MOTTA(1994).

Para cumprir essas funções, os reservatórios foram dimensionados com capacidade útil destinada a atenuar as ocorrências de inundações de extensas áreas ribeirinhas e, também, para manutenção de deflúvios mínimos no rio, com vistas à diluição dos efluentes e, assim, possibilitar as tomadas de água do rio para propósitos secundários. Dentre estes, merecem destaque: a irrigação do cinturão verde a jusante da barragem e a utilização do reservatório para fins recreativos.

\subsection{4 - Histórico da Construção da Barragem do Jundiaí}

Das obras planejadas, as Barragens de Ponte Nova e Taiaçupeba foram concluídas em 1979. As obras da Barragem do Rio Jundiai começaram em 1977. Estiveram paradas, e/ou em ritmo muito lento, devido a problemas que o órgão empreendedor, o DAEE, pertencente à administração pública direta, enfrentou no periodo. A Barragem foi concluída em 1987, embora só tenha entrado em operação em 1990, e a necessária interligação com a Barragem de Taiaçupeba somente foi concluída em 1991. Essa interligação do reservatório de Jundiaí com o de Taiaçupeba, e daí para a Estação de Tratamento, permite que as duas barragens operem conjuntamente e forneçam mais benefícios à população.

\footnotetext{
${ }^{3}$ MALER, K. G. \& WIZGA, R. E. La Measure Economique des dommages dans le domain de l'environment. Paris: O.C.D.E., 1976,.161 p.
} 


\subsection{5- Descrição da Bacia Hidrográfica do Rio Jundiaí}

O rio Jundiaí é um afluente da margem esquerda do rio Tietê. Conforme a Divisão Hidrográfica aprovada pelo Conselho Estadual de Recursos Hídricos, pertence ao Terceiro Grupo de bacias, o Alto Tietê e sua bacia hidrográfica tem uma área de drenagem de $111 \mathrm{~km}^{2}$. O Rio Jundiaí pertence à região definida como de Proteção aos Mananciais da Região Metropolitana de São Paulo, pela Lei Estadual ${ }^{\circ}$ 898/75.

Essa lei é um instrumento legal que disciplina o uso do solo para proteger os recursos hídricos da Região Metropolitana de São Paulo e para garantir a existência de água suficiente e de boa qualidade para a população. A Barragem faz o rio Jundiaí inundar uma área de aproximadamente $17,5 \mathrm{~km}^{2}$. Os recursos Hidricos acumulados no reservatório formado pela barragem do Jundiaí vão para o de Taiaçupeba, e daí para a estação de tratamento de água do Alto Tietê, da SABESP, de onde é encaminhada para o abastecimento da Região Metropolitana de São Paulo. Esse complexo gera uma oferta que tem aumentado com o crescimento do aproveitamento na Barragem de Taiaçupeba. Esse padrão de vazão regularizada, vai se tornar insuficiente em prazo relativamente curto, para atender a mesma região para qual hoje ela vem fornecendo, água à contento. Esse fato implica a racionalização do uso da água na construção de novas barragens e no reestudo da problemática, visando para a implantação de incentivos econômicos para redução das demandas hídricas ( Ex: a cobrança pelo uso da água).

A premência dos estudos sobre 0 assunto foi determinada pela Lei $n^{\circ}$ 7.663, de 30/12/1991, que estabeleceu uma Nova Política de Recursos Hidricos para o Estado. Ademais, foi aprovado recentemente o Plano Integrado para Gerenciamento de Recursos Hídricos das Bacias do Alto Tietê, Piracicaba e Baixada Santista, instrumento essencial para definição de objetivos, metas e investimentos de curto, médio e longo prazo e estabelecimento dos investimentos requeridos. 


\section{3 - Barragens}

Fazer barragens em rios, é uma obra impactante, mas pode ser uma boa solução para resolver problemas energéticos de países com bom potencial hidroelétrico, como o Brasil. A seguir, descreve-se resumidamente essas obras de engenharia, tomando-se por base o caso em estudo.

\subsection{1 - Barragem de Terra}

"Barragem", como é conhecida popularmente, é composta de um maciço (barragem) de terra e de um conjunto de concreto armado, que compreende a tomada de água, casa de força (quando barragem hidroelétrica), vertedouro e "hall" de montagem.

A barragem de terra é o elemento edificado com a finalidade de barrar o curso d'água e proporcionar a formação do reservatório. O material essencial (terra) à construção da barragem de terra é previamente localizado através de estudos de prospecção geológica, tendo como parâmetros à exploração fatores técnicos (mecânica dos solos) e econômicos (distância de transporte); que devem ser compatibilizados com fatores ecológicos e estéticos.

As áreas destinadas à exploração, denominam-se áreas de empréstimo de terra, que é o caso do local em estudo. O tamanho destas variam conforme - relevo da área e a necessidade de terra para formação do maciço da barragem. A área de empréstimo é praticamente uma área que foi minerada, tal o desgaste imposto ao local. Antes da utilização é feito um decapeamento (retirada de todo o tipo de cobertura).

\subsection{2 - Barragem de Concreto}

Essa parte da obra é edificada em concreto armado. Dois elementos básicos compõem o concreto: areia e pedra britada. São extraídos de jazidas próxima à obra, seguindo os mesmos critérios de exploração das áreas de empréstimo de terra. A estrutura da barragem de concreto pode ser vista na Figura 6. 


\subsection{3 - Escolha da Área de Empréstimo}

Parâmetros técnicos baseados na mecânica dos solos (escolhe-se a fração argila do solo não porosa e pouco permeável) e parâmetros econômicos, como distância de transporte, determinam a escolha das áreas a serem exploradas. Normalmente, as áreas de empréstimo de barragens, situam-se na própria bacia de inundação destas. Mas na Barragem do Jundiaí, não foi isso que ocorreu. Como neste caso, existem muitas áreas de empréstimo também degradadas no país. Após a determinação das áreas possiveis de serem exploradas, deveriam ser analisados os fatores ecológicos e estéticos. Eles seriam considerados, com o objetivo de minimizar os impactos ao meio ambiente. Os estudos feitos para construção da Barragem do Jundiai não contemplam esse aspecto essencial.

\subsection{4 - Exploração e Características Necessárias às Áreas de Empréstimo}

Após determinada a área a ser explorada, ela é dividida em "tabuleiros", dos quais são extraídos os volumes de terra necessários à obra, previamente fixados pelas sondagens. A operação inicial na exploração é a retirada de tudo o que existe sobre o solo e remoção da camada superficial de solo, denominada horizonte A. Isso é feito até que se expõe a camada de solo a ser utilizada como empréstimo, normalmente o horizonte $C$. Nas áreas de empréstimo de solo, cada tabuleiro é escavado mecanicamente até a profundidade em que se dá a transição do tipo de solo não utilizável para a construção, até o solo aproveitável, geologicamente chamado, solo de alteração. Em conseqüência dessa exploração, feita com equipamentos pesados, o solo remanescente das áreas de empréstimo fica altamente compactado, com coeficiente de infiltração baixo, formando-se bacias muito susceptíveis à erosão. Além disso, com a retirada da camada de solo superficial, o restante pressupõe-se ser extremamente pobre. Nesse caso, a situação ainda se agrava, quando sabe-se que o solo explorado tem como rocha matriz um granito (deveria ser um solo podzólico), o qual, por possuir um horizonte $\mathrm{B}$ textural, é mais sujeito à erosão. 


\section{4 - Descrição da Construção da Barragem do Jundiaí}

Os locais próximos à Barragem são usados primeiramente como canteiro de obras. Depois, devido ao planejamento da obra e ao método construtivo adotado, faz-se uma ensecadeira no rio, a fim de secá-lo para se fazer o resto da obra. Após isso, escava-se o local $\left(1.476 .000 \mathrm{~m}^{3}\right)$ onde será feito o maciço. Retira-se a terra porosa e permeável até onde as sondagens preliminares indicam haver as condições geofísicas para se iniciar o aterro que formará o maciço da barragem. Isso é realizado quando se atinge o solo impermeável, denominado solo de "alteração".

O maciço da barragem, como foi explicado, necessita de terra de determinada qualidade. Para construção do maciço, a terra é escolhida nas proximidades, através de sondagens e análises. Estas, pelo que pode ser observado, levam em conta principalmente a geologia do subsolo para o devido aproveitamento na construção do maciço. Não existiu a menor preocupação com o que havia na camada superficial do solo de empréstimo e sobre ele, nem sequer foram feitos estudos sobre o assunto. Houve uma certa preocupação com a área que foi inundada pela barragem. A área escolhida para retirada de terra foi, então, denominada área de empréstimo. Nesse local, realizou-se primeiro o desmatamento e retirou-se toda a parte orgânica do solo, porosa e imprestável, para a construção do maciço (na época, início de 1977). Essa parte orgânica, inclusive, foi jogada fora. Depois de retirada a parte da terra que interessava, ela foi mandada para o local da barragem, onde, após compactação, formou-o maciço. Posteriormente, a área utilizada foi abandonada, sem cobertura vegetal nenhuma e sem os muitos metros de solo retirados. Alguns destes, mais precisamente1.925.000 ${ }^{3}$, foram utilizados no maciço da barragem e outros, que não se pode precisar quantos, foram simplesmente jogados fora, dispostos em qualquer lugar. 


\section{5- Cálculo da Área de Empréstimo, Local do Estudo de Caso}

A área de estudo, com 130 ha, foi calculada a partir de planimetria de um mapa da área, em escala 1: 50.000 em que se locou a área de empréstimo, com o auxílio de um levantamento de campo (infelizmente apenas altimétrico). Este levantamento foi realizado em 1994, pelos próprios técnicos do D.A.E.E., com objetivo de se conhecer a topografia local para posteriormente se proceder a recuperação da mesma.

As técnicas utilizadas trazem imprecisão. Assim, para complementar as informações desses levantamentos, utilizou-se uma janela selecionada em uma imagem do satélite LANDSAT-5, cuja resolução espacial é de 30 metros. O processamento digital utilizou os recursos do produto Sistema Geográfico de Informações (S.G.I.), desenvolvido pelo Instituto Nacional de Pesquisas Espaciais - I.N.P.E.. A imagem é de 2 de março de 1993.

O produto final do processamento é uma composição de falsa cor no espaço R.G.B., a partir das bandas 3, 4 e 5, cuja ampliação fotográfica tem escala aproximada 1:35.000 e foi impressa em uma copiadora jato de tinta, como mostra a Figura 5.

$\mathrm{Na}$ tela mostrada no computador, foram vetorizadas as áreas, interpretadas como as de empréstimo. Suas dimensões foram calculadas mediante contagem dos "píxels" 4 compreendidos nos poligonos vetorizados, com o uso de aplicativos computacionais. A área obtida por esse método foi aproximadamente a mesma do primeiro método. Comparando-se os métodos utilizados, verifica-se que o primeiro possui imprecisão no modo de cálculo da área, e o segundo tem imprecisão decorrente da própria interpretação da imagem.

O erro na interpretação das cores pode ser ampliado pelo tamanho da resolução da imagem do satélite LANDSAT- 5 (píxel de $900 \mathrm{~m}^{2}$ ). 


\section{6- Clima da Região}

O clima da região pode ser considerado, segundo a classificação de Koeppen, como da variedade Cwb, isto é, clima de savana dos altiplanos tropicais com verão ameno e média de temperatura máxima diária de $24,30^{\circ} \mathrm{C}$ e mínima de $13,80^{\circ} \mathrm{C}$. A umidade relativa do ar média é de $83 \%$ e os ventos são relativamente brandos. Os verões possuem noites frescas (grandes amplitudes térmicas diárias). A região está situada relativamente próxima à Serra do Mar e, assim, possui maior uniformidade na distribuição das chuvas durante o ano. Pode-se considerar os meses de outubro a março como os mais chuvosos e, assim, o período de abril a setembro como o menos chuvoso. Esses dados, importantes para o correto dimensionamento do projeto de recuperação, são apresentados na Figura 7.

\section{7 - Dados Físicos da Barragem do Rio Jundiaí}

São apresentados, a seguir, os dados mais significativos do projeto de engenharia da Barragem do Rio Jundiai. A Figura 6, mostra um corte transversal da Barragem de concreto com as principais seções.

1) Bacia

Área de drenagem: $111 \mathrm{~km}^{2}$

Área de inundação (N.A. máximo normal): 17,5 km²

Área desapropriada: $19,10 \mathrm{~km}^{2}$

Propriedades desapropriadas: 227

2) Reservatório

N.A. mínimo útil normal: $750,0 \mathrm{~m}$

N.A. máximo útil normal: $754,5 \mathrm{~m}$

N.A. máximo maximorum: $756,78 \mathrm{~m}$

volume útil do reservatório: $60 \times 106 \mathrm{~m}^{3}$

volume total do reservatório: $148 \times 106 \mathrm{~m}^{3}$

3) Barragem

Cota da Crista: $758,00 \mathrm{~m}$ 
Comprimento: $690,00 \mathrm{~m}$

Largura: $10,00 \mathrm{~m}$

Altura Máxima: $23,00 \mathrm{~m}$

Volume de Escavação: $1.476 .000,00 \mathrm{~m}^{3}$

Volume de Aterro: $1.925 .000,00 \mathrm{~m}^{3}$

4)Descarregador de Fundo

Dimensão da Galeria: 4,00 × 3,5 $\mathrm{m}^{3}$

Vazão Regularizada: $2,1 \mathrm{~m}^{3} / \mathrm{s}$

Volume de Concreto: $3605,00 \mathrm{~m}^{3}$

5)Canal Vertedouro

Cota do Creager: $754,5 \mathrm{~m}$

Volume de Concreto: $1470 \mathrm{~m}^{3}$

Habitantes Beneficiados (aprox.): 1.300 .000

\section{8 - Custo da Barragem do Rio Jundiaí}

Conforme informações recebidas através do Departamento de Obras do D.A.E.E., a Barragem do Jundiaí teve um custo aproximado de 43 milhões de dólares, isso incluindo o pagamento da área desapropriada e a realocação de estradas. Observando-se no item seguinte, dados físicos da Barragem, 0 único dado nessa que se ressalta de outras Barragens é o volume de escavação.

\section{9 - Metodologia Aplicada ao Caso}

No caso, a avaliação direta dos benefícios perdidos (biodiversidade, capacidade de suporte da fauna e da flora, fixação do solo, manutenção dos ciclos minerais, do carbono e da água, e com isso manutenção do microclima e de todas as outras funções ambientais que fazem com que os sistemas ecológicos sirvam de sustentação à vida e aos sistemas econômicos) tornou-se praticamente impossível. Como se está fazendo uma avaliação a posteriori, após ocorrido o dano, a determinação de tudo o que havia no local (plantas, 
animais, minerais) para a realização de uma avaliação direta tornaram-se inviáveis. Também seria uma redução absurda da importância da capacidade de suporte dos ecossistemas e de sua complexidade o uso, simplesmente, do valor do metro cúbico de terra, da maneira como ele é usado em orçamentos de obras civis em geral; ou seja, seu valor de mercado, para compra de metro cúbico de terra, multiplicado pela quantidade de terra retirada para a obra. Esse valor encontrado não pode ser considerado como o valor que deve ser dado ao dano causado à área de empréstimo. Outras técnicas que foram apresentadas também são inviáveis, como os métodos de valoração contingencial, principalmente porque o dano ao meio ambiente ocorreu há vários anos, e não foram feitos estudos pedológicos, botânicos, zoológicos, sociológicos, fitossociológicos que visassem à recuperação posterior da área, como já fora descrito no histórico da construção da obra.

Dessa forma, optou-se por calcular, primeiramente, o custo de reposição da área o qual deve refletir minimamente o custo de reabilitação das funções ambientais que eram providas anteriormente por esta. Com esse objetivo, fez-se um projeto de recuperação para toda a área degradada $e$ estimou-se quanto custaria esse projeto, se ele realmente fosse implantado atualmente.

Esse valor, entretanto, não pode ser considerado o valor econômico total dos recursos naturais degradados na área, primeiramente porque não se terá uma reposição completa (ela será a melhor e mais importante, será uma reposição viável, dentro dos conhecimentos atuais). O período total em que o solo ficou exposto, estéril, sem realizar suas funções ambientais também é necessário ser valorado. Então, devido aos mesmos problemas expostos anteriormente, optou-se por um método de valoração indireta: calculou-se o custo de oportunidade para a área de empréstimo e, que por isso, foram perdidos todos os benefícios que poderiam ter sido por ela gerados.

Os beneficios produzidos pela área são considerados bens intangíveis. Esses benefícios são um fluxo de receitas gerados pelo ecossistema local, que é um bem patrimonial , estoque. Apesar disso, exploratoriamente, usa-se como abordagem mais adequada, baseada no arsenal teórico da economia 
neoclássica calcular-se o fluxo de receitas, que poderiam ser geradas pelo melhor uso alternativo, da área degradada. Usa-se o valor obtido como se fossem os benefícios perdidos gerados pelo ecossistema Assim, optou-se por calcular as receitas, que poderiam ser geradas pelo melhor uso alternativo, da área degradada representam os benefícios perdidos. Da mesma maneira como DIXON (1991) utiliza-os comparando essa receita com a preservação da área e considerando-a por principiomenor que os benefícios intangíveis da preservação.

O valor anual das receitas que poderiam ser geradas na área é calculado para todos os anos que se passaram desde o tempo em que houve o início da degradação (1977) e ela se transformou nesse estado quase desértico até quando, após a implantação do projeto de recuperação, se obtém o restabelecimento da dinâmica do ecossistema da área. De acordo com um especialista no assunto (Eng.agr. Jânio Carlos, da CESP), isso deve ocorrer após aproximadamente dois anos de implantação do projeto. Considerando-se que o projeto seja implantado em 1995, em 1997 já se teria a área com sua dinâmica ecológica restabelecida.

O que se propõe, e isso deve ficar claro, é a recuperação da dinâmica do ecossistema degadado (130 ha), e não a completa recomposição da área. O valor das receitas que poderiam ser obtidas no terreno durante esses anos, mas não foram, é trazido para o presente, sendo os preços atualizados. Assim, obtém-se um valor que pode representar a ordem de grandeza dos benefícios perdidos pela sociedade como um todo devido a utilização de uma área como empréstimo quando, posteriormente a exploração, não se promove sua recuperação. Segundo DIXON (1991), equipara-se os benefícios perdidos, que poderiam ter sido produzidos na área nesse período, como o custo de oportunidade do terreno usado como empréstimo. No entanto, considera-se que as receitas referentes ao custo de oportunidade (ou as receitas recebidas) são menores do que os benefícios intangiveis da preservação. Esse valor - somado à previsão do custo da recuperação da área e mais alguns benefícios qualitativos praticamente impossiveis de serem valorados e que serão considerados apenas qualitativamente - dá uma noção 
pragmática do dano ambiental monetário provocado pela utilização da área como empréstimo. Esse valor é bem diferente do valor da área de terra ou do valor dos benefícios perdidos pela área total degradada pela barragem, o qual seria usado em uma análise custo/benefício completa da barragem. Esta, sim, poderia ser comparada com os benefícios gerados pela barragem. 


\section{4 - APLICAÇÃO DA TÉCNICA DE AVALIAÇÃO ECONÔMICA SELECIONADA PARA O CASO DE ÁREA DE EMPRÉSTIMO}

O caso é a aplicação de técnicas de avaliação econômica de recursos naturais para o cálculo da soma monetária referente ao dano imposto a uma área de empréstimo, próxima à barragem do Rio Jundiaí. Hoje, o local é um terreno totalmente exposto, praticamente sem vegetação, como pode ser visto na Figura 2. Isso ocorre desde o início de 1977, quando do começo das obras para a construção da Barragem do Rio Jundiaí. A princípio, foram feitos os canteiros da obra, depois o desmatamento de toda a área que iria ser utilizada e dos acessos, bem como a raspagem do solo, retirando-se toda a parte orgânica. Após isso, foi retirada a porção de solo impermeável que depois de compactação seriai usada no maciço da barragem. Esses materiais devem ser argilosos e/ou siltosos; portanto, em cada área só se aproveitaram os horizontes que possuiam essa granulometria. Como o solo se forma em camadas, desse modo foi necessário retirar e jogar fora grande quantidade de resíduos antes de se atingir as camadas de interesse. Quando se atingiu a argila ou o silte, foram retirados $1.925 .000 \mathrm{~m}^{3}$ de solo, que foram levados do 
local de origem para a barragem e constituíram, após compactação, o seu maciço. Na maior parte do terreno, foram retirados os horizontes pedologicamente conhecidos como $\mathrm{A}$ e $\mathrm{B}$, restando somente o horizonte $\mathrm{C}$, já com presença de fragmentos grosseiros de rocha.

A retirada de terra como empréstimo para a indústria da construção em geral, poderia ser uma prática que não provocasse tantos danos se fosse feito um trabalho com preocupações ambientais. Não foi feito praticamente nenhum trabalho de recuperação da área desde essa época, somente o plantio de uns poucos pés de pinus, que, sem as práticas de recuperação complementares necessárias, não mudaram em praticamente nada a situação do terreno. Ele continuou totalmente estéril e sem produzir nada para a sociedade.

\section{1 - Aplicação das Técnicas de Avaliação de Recursos Naturais Selecionadas na Área de Empréstimo Abandonada do Rio Jundiaí}

\subsection{1 - Projeto de Recuperação}

Tendo em vista que uma das metodologias escolhidas foi o custo de reposição, apresentam-se, a seguir, um projeto de recuperação da área degradada e, posteriormente, a previsão dos seus custos, estimados em dólares americanos.

O programa de recuperação dessa área tem como objetivos fundamentais:

- a recuperação da flora e da maior parte possível das funções ambientais do ecossistema local; e

- a conservação, proteção e sustento da fauna silvestre regional, isto é, o restabelecimento da capacidade de suporte da área.

Como conseqüência, têm-se o controle dos processos erosivos e a reserva da área para utilização futura em consonância com as necessidades das comunidades envolvidas. 
Para atingir tais objetivos, é necessária a utilização de técnicas que promovam a recuperação física, química e biológica da área. O processo deve ser entendido como de longa maturação, viabilizado através da implantação de obras de controle de erosão e de reflorestamento com espécies nativas da região, associado à capacidade de regeneração da natureza.

Esse processo visa à formação, ou melhor, à recuperação de um ambiente auto-sustentável, a fim de que populações de animais e plantas possam ter restabelecidos seus processos dinâmicos e suas funções ambientais, que a natureza provia naquela área antes que ela fosse utilizada como empréstimo.

A área, após a degradação, passou a ter algumas características peculiares que podem dificultar muito seu processo de recuperação. A seguir, descreve-se como a área foi encontrada.

A quantidade de nutrientes no terreno é baixíssima. Esse terreno, do tipo distrófico (ver Tabela 1), possui capacidade de troca catônica ínfima e, portanto, a simples adição de fertilizantes no solo é insuficiente (é necessário adicionar nele matéria orgânica de forma bruta, em grandes quantidades). Apresenta erosão laminar acentuada, principalmente devido à inexistência de cobertura vegetal na área.

Essa situação só não se agrava porque o relevo se apresenta entre plano e ondulado, mas principalmente a primeira forma. Assim mesmo, ocorre um processo intenso de erosão linear, do tipo voçorocas. O terreno tem, ainda, um solo compactado devido ao trabalho das máquinas pesadas, o que deve causar muitos problemas para a recuperação da área.

Praticamente não existe banco de sementes viáveis no substrato. Existem poucas reservas de flora ou fauna remanescentes na região do entorno que possuam possibilidade de dispersão das sementes para esta. Para cumprir os objetivos iniciais, implantam-se, então, espécies pioneiras combinadas com espécies com exigências complementares, principalmente quanto à exigência de luz. Mas o restabelecimento da dinâmica de sucessão vegetal só deve ocorrer após um período de tempo razoável, quando as espécies pioneiras 
plantadas forem sendo substituídas pelas espécies clímax, as quais vão se reproduzir, estabelecendo-se e tomando conta de toda a área. Não existe literatura que possa precisar o período de tempo necessário para que isso aconteça.

Tabela 1: Médias Das Dez Amostras De Solo Retiradas Da Área de Empréstimo

da Barragem do Rio Jundiaí -São Paulo

\begin{tabular}{cccccc}
$\begin{array}{c}\text { Índice de } \\
\text { acidez } \\
\mathrm{PH}\end{array}$ & $\begin{array}{c}\mathrm{P} \\
\text { Fósforo em } \\
\text { resina } \\
\mathrm{CaCl}\end{array}$ & $\begin{array}{c}\mathrm{M} \text {. O. O. } \\
\mathrm{g} / 100 \mathrm{ml}\end{array}$ & $\begin{array}{c}\text { C.T.C. } \\
\text { Capacidade de } \\
\text { troca catiônica } \\
\text { meq/100ml }\end{array}$ & $\begin{array}{c}\text { Saturação em } \\
\text { bases } \\
\text { meq/100ml }\end{array}$ & $\begin{array}{c}\mathrm{V} \\
\%\end{array}$ \\
\hline 4,3 & 3,6 & 0,9 & 4,38 & 0,77 & 16 \\
\hline
\end{tabular}

Fonte: D.A.E.E.

Quando não é previsto o início da recuperação das áreas degradadas antes do término da obra as práticas necessárias a recuperação tornam-se mais onerosas, e a possibilidade de não ser satisfatória é maior. Além disso, no caso em estudo, passaram-se muitos anos, e o estado de degradação se agravou. A erosão se alastrou por toda a área, formando grandes sulcos: as voçorocas.

Como existem poucos trabalhos relacionados à recuperação de áreas de empréstimo, contou-se com o auxílio de um especialista em solos (Professor Gerd Sparovek, ESALQ-USP) que vistoriou a área com esse objetivo. Ademais, foram realizadas várias discussões técnicas sobre o projeto com especialistas de outras áreas.

Tomando-se por base um trabalho publicado pela CESP (1992) sobre o assunto foi então elaborado o projeto de recuperação da área de empréstimo. Este projeto é essencialmente viável e não tem a pretensão de incorporar todos 
os valores perdidos na área degradada. Aliás, quanto a degradação de uma área ser irreversivel ou não, existem controvérsias. Alguns economistas sustentam que é possivel recuperar áreas com aplicação suficiente de capital e tecnologia (CUMMINGS e NORTON, 1974; apud DIXON, 1991), enquanto outros sustentam a tese de que é impossivel recriar fielmente ambientes degradados de maneira aceitável para os diversos usuários (FISHER, KRUTILLA E CICCHETTI, 1974; apud DIXON, 1991).

O Projeto de Recuperação compreende as seguintes operações:

Fase 1: Reafeiçoamento e sistematização do terreno

* Regularização e fechamento dos sulcos

A exploração da área para retirada do material de empréstimo é feita com máquinas pesadas e equipamentos de grande porte e capacidade operacional, em ritmo acelerado, deixando fortes marcas no terreno em forma de cortes abruptos, os quais se transformaram em sulcos de erosão devido à ação de águas das áreas adjacentes à bacia formada. Esses cortes são ampliados em virtude do solo ter se mantido sem cobertura vegetal por todos esses anos.

Deve-se iniciar a recuperação da área pela regularização dos sulcos. Com um trator de esteira com lâmina frontal, iguala-se o terreno distribuindo-se a terra com fragmentos grosseiros ainda remanescentes por um tabuleiro, fechando-se os sulcos de erosão e abrindo-se acessos. Estes devem permitir a movimentação de veículos e equipamentos necessários à implantação e à manutenção do reflorestamento.

* Terraceamento

A área de empréstimo no caso, pode ser comparada a uma área lavrada (de lavra mineral), que não possue nenhuma cobertura vegetal, mesmo no caso estudado, que a área fora explorada há vários anos. Como os solos são de baixa infiltração, baixa resistência e tolerância à erosão, eles possuem pouca espessura devido à destruição quase total dos horizontes superficiais, restando somente o horizonte $\mathrm{C}$ com grande presença de cascalho, mas pouca 
declividade. Todavia, é importante fazer o terraceamento da área, principalmente porque ser a rocha matriz do solo um granito (o solo deveria ser podzólico) e, portanto, teoricamente mais sujeito a problemas de erosão.

O objetivo de se fazer o terraceamento da área é minimizar o efeito erosivo das chuvas, através da diminuição da rampa de declive. Ela provoca a diminuição da energia cinética da enxurrada, ocasionada pelas chuvas. A força da enxurrada cresce (energia cinética) ao longo da declividade do terreno, mas o terraceamento força a parada e o aumento da infiltração da água no solo pelo maior tempo de contato. Existem tabelas elaboradas para práticas conservacionistas na agricultura, que podem também ser adotadas neste caso. Essas tabelas estabelecem limites máximos de distanciamento horizontal e vertical entre os terraços, variando de 30 metros (horizontal) a 2 metros (vertical). Neste projeto, a distância entre os terraços varia dependendo da declividade do terreno. O gradiente dentro do terraço não deve ultrapassar a $0,5 \%$, e este deverá conduzir a água excedente para um canal escoadouro, a ser construído, que deve ser coberto por vegetação para evitar a ocorrência de erosão dentro do próprio canal. Se possivel, esse canal deve seguir os canais naturais de drenagem já existentes no terreno.

\section{* Abertura de acessos}

A fim de se permitir a movimentação de veículos e equipamentos necessários à implantação e à manutenção do projeto de recuperação, deve ser projetada uma malha de caminhos mais largos (primários) e mais estreitos (secundários). A circulação primária deverá ser executada com equipamento dotado de lâmina, comlargura próxima a 6 metros.

Não se pode concluir sobre o tempo necessário para que ocorra uma nova gênese do solo a partir das rochas remanescentes. O que existe sobre 0 assunto é de caráter experimental. Portanto, o projeto somente garante o restabelecimento das condições para reinício dos processos de formação do solo. Não faz sentido destruir uma nova área, retirando-se o solo do local, para poder recuperar uma outra, já degradada. Assim, nesse projeto não será previsto o carregamento de terra de uma nova área para recuperar a que já foi degradada. A recuperação ideal, perfeita de uma área não se considera 
mesmo possivel, por isso o projeto contempla a reposição de matériais apenas nas covas de plantio. Portanto, não será reposta a parte orgânica do solo, a camada de cobertura e, como em alguns lugares a camada de solo restante é infima, não haverá necessidade de preparo de solo. Sem a reposição, estando-se na maior parte da área no horizonte $\mathrm{C}$, onde existem muitos fragmentos de rocha, praticamente não existe solo a ser preparado.

Considerando que seria extremamente dispendioso e desnecessário recuperar as condições do solo em toda área, será feito todo o trabalho de recuperação das condições para crescimento da vegetação na cova de plantio. Isso será como se realizasse o plantio em um vaso, mas não haverá problemas, desde que através da sulcação se promovam boas condições de drenagem, Restabelecem-se, assim, as condições ambientais ideais para o crescimento vegetal. Para tanto, serão feitas operações de desagregação, colocação de matéria orgânica, correção de pH e correção de fertilidade do solo. Sabe-se das limitações do método escolhido para uma verdadeira recuperação de todos os valores perdidos na área, mas é uma alternativa viável de ser implementada.

\section{Fase 2: Recomposição Vegetal}

A recomposição vegetal da área visa restabelecer as funções ambientais do ecossistema. Busca, ainda, restabelecer as condições preexistentes na área, tais como manutenção do clima, regularização do ciclo hidrológico, restabelecimento da pedogênese, diversificação genética e restabelecimento do processo evolutivo. Assim poderá se assegurar a perenização e auto-sustentabilidade do ecossistema degradado.

*Espécies escolhidas e implantação com sulcação

Conforme explanado, são selecionadas, dentre espécies nativas, espécies pioneiras e secundárias iniciais (mais da metade), para que façam uma boa cobertura do local, e uma quantidade menor de espécies secundárias tardias e clímax. Para se evitar maiores comprometimentos da área, propõe-se a escolha de um viveirista que produza mudas de plantas nativas de qualidade, de pequeno porte (aproximadamente $30 \mathrm{~cm}$ ), ao menor custo encontrado. Elas 
devem ser plantadas no local no menor prazo possivel após a compra, para que não se incorra em outras despesas.

O plantio propriamente dito é feito usando-se um trator com sulcador para marcação das covas em nível, obedecendo ao espaçamento de $3 \times 1,5 \mathrm{~m}$; portanto, serão feitas 2.222 covas por hectare. Essa operação conjugada marcação das covas e sulcação - é muito importante, porque vai permitir que as raízes das plantas cresçam e penetrem nos espaços formados pelos fragmentos de rocha do solo remanescente, e depois se expandam para além da área da cova. Na cova, criam-se condições ideais para o crescimento inicial das mudas, que, porém, precisam de mais espaço para continuar crescendo. $\mathrm{Na}$ fase posterior, já não necessitam de condições tão perfeitas, pois estarão mais robustas. As covas são abertas com uma dimensão aproximada de $40 \mathrm{x}$ $40 \times 40 \mathrm{~cm}$. Nelas, são aplicados calcário, esterco (matéria orgânica) e adubo químico ( fórmula N-P-K ). Essa prática é realizada manualmente, a lanço, conjugada com outra operação manual, embora feita com a enxada, que deve promover a mistura de todos os elementos adicionados, ao solo remanescente, existente na cova.

A necessidade de calagem é recomendada pelo método IAC (Boletim Técnico no-100), suficiente para aumentar a Saturação em Bases ( $\%$ ) até 55$60 \%$. A adubação recomendada é de 20 toneladas de esterco de vaca e 450 gramas por cova, da fórmula de adubo de plantio, 4-14-8.

Plantio e replantio são considerados juntos para efeito do dimensionamento das necessidade de mudas. Assim, calcula-se que serão necessárias 2.500 mudas por hectare. A luz solar é o recurso natural mais abundante que para ser bem aproveitado, sugere-se o plantio no método do quincôncio, intercalando-se plantas com mais e menos exigências de luz e umidade. As plantas são distribuídas na seguinte proporção: $75 \%$ de espécies pioneiras e secundárias iniciais; e $25 \%$ de espécies secundárias tardias e clímax. Intercala-se uma linha de espécie pioneira com uma de espécie secundária, como mostra o esquema a seguir. 


$$
\begin{array}{ccc}
\mathbf{X} & \text { Pioneira ou secundária inicial }=\mathbf{X} \\
\mathbf{X} & \text { Clímax ou secundária tardia }=\mathbf{0} \\
\mathbf{X} & \\
\hline
\end{array}
$$

Ao final de vários anos, haverá presença dominante de espécies clímax. Contudo, também não existem trabalhos experimentais suficientes que determinem o tempo necessário para que isso ocorra. Ademais, são muitos os fatores que levam à recuperação ou não de uma área; por isso, recomenda-se fazer primeiro um projeto-piloto em uma área menor $e$, depois, executar o projeto na área total.

* Tratos Culturais e Manutenção da Área

Após colocar a muda na cova preparada, é necessário irrigá-la até o pegamento, combater as formigas, adubar em cobertura (uma vez, no primeiro ano) e limpar em volta da muda (coroamento). Nesse caso, considera-se que não há a necessidade de trabalho de roçada na área total, tal a inexistência de vida no solo (ver Figura 2). Assim, propõe-se que deva ser feita somente uma roçada, no primeiro ano. Esse trabalho se justifica, porque o material que fora trazido de fora, poderá conter sementes de espécies daninhas, uma vez que a área era praticamente estéril. Mas, a partir do segundo ano após o plantio, não serão mais necessárias despesas de manutenção, nem insumos materiais a serem introduzidos pelo homem, que oneram muito o projeto. Dessa forma, em dois anos pretende-se que seja restabelecida a dinâmica do ecossistema local.

O ecossistema recuperado, entretanto, não será igual ao que existiria no local se não houvesse a intervenção antrópica. $O$ mais importante, porém, é que os processos que ocorriam no meio ambiente impactado se restabeleçam e esse ambiente volte a prestar benefícios à sociedade (bens intangiveis e tangiveis). Com o arsenal teórico hoje 
existente, esta é uma das opções que podem ser feitas, de fato, para a recuperação da área de empréstimo degradada 


\section{5 - Resultados}

Os resultados serão apresentados, separadamente, para valor estimado do projeto de recuperação, valor estimado do custo de oportunidade da área de emprésimo e os valores qualitativos.

\section{1 - Estimativa do Custo do Projeto de Recuperação}

A estimativa do custo do projeto de recuperação da referida área de empréstimo foi feita baseada em três centros de custo: Reafeiçoamento do terreno, Recomposição vegetal e Insumos.

Para efeito de cálculo, o custo do projeto é apresentado em forma de planilha, com colunas que representam a operação, o tipo de equipamento usado, o rendimento por unidade adotada, o custo pela unidade adotada, o custo por hectare e o custo dos 130 ha degradados. Os preços procuram refletir valores presentes. Para tanto, adotou-se o dólar como unidade monetária de referência. 
A maior parte dos coeficientes técnicos usados têm por base os dados aceitos pela Companhia Energia de São Paulo - C.E.S.P., que trabalha com barragens e recuperação de áreas degrdadas, no Estado de São Paulo. Os rendimentos de máquina também têm a mesma origem; alguns podem ser considerados rendimentos muito baixos, mas isso se explica porque eles se referem a trabalhos executados em solo muito difícil de ser trabalhado, pois estes foram bastante compactados pelas máquinas usadas na exploração.(ver Tabela 1). 
Tabela. 2: Planilha de Previsão de Custos do Projeto de Recuperação da Àrea De Empréstimo, Barragem Do Jundiaí

\begin{tabular}{|c|c|c|c|c|c|}
\hline OPERAÇÃO & EQUIPAMENTOS. & QTDE./HA. & $\begin{array}{l}\text { CUSTO/UN } \\
\text { (US\$) }\end{array}$ & $\begin{array}{l}\text { CUSTO } \\
\text { US\$/HA }\end{array}$ & TOTAL \\
\hline \multicolumn{6}{|l|}{$\begin{array}{c}\text { REAFEIÇOAMENTO } \\
\text { DO TERRENO }\end{array}$} \\
\hline terracean & D 6 & 16h/ha & 49,636 & 794,176 & $103.242,88$ \\
\hline manut. $c$ & $\mathrm{D}$ & 8 & 36 & 397,088 & 51.6 \\
\hline \multicolumn{6}{|l|}{ RECOMP.VEGETAL } \\
\hline combal & & $30 \mathrm{~h}$ & 0,940 & 28,20 & $3.666,00$ \\
\hline comb & & 10ho & 0,940 & 9,40 & 2,00 \\
\hline const & motoniv. & $2 \mathrm{~h} / \mathrm{ha}$ & 32,231 & 64,46 & ,06 \\
\hline $\begin{array}{l}\text { marcação de cova } \\
\text { c/ subsolagem }\end{array}$ & D6 +subsolador & $2 \mathrm{~h}$ & 50 , & 100,07 & ,36 \\
\hline coves & & 150 & $0, \varsigma$ & & , 00 \\
\hline adu & & & & & \\
\hline \multirow{2}{*}{$\begin{array}{l}\text { distrib. de } \\
\text { mudas }\end{array}$} & trator+carr. & $3 \mathrm{~h}$ & 15 & & \\
\hline & & $25 \mathrm{~h}$ & & & \\
\hline \multirow{2}{*}{$\begin{array}{l}\text { distrib. de } \\
\text { calcáreo }\end{array}$} & trator+carr. & $3 \mathrm{~h}$ & 15 & 46 & ,30 \\
\hline & & $15 \mathrm{~h}$ & 0, & & \\
\hline \multirow{2}{*}{$\begin{array}{l}\text { distrib.de } \\
\text { adubo }\end{array}$} & trator+carr & $3 h$ & 15, & 41 & 30 \\
\hline & & $15 \mathrm{r}$ & & & \\
\hline \multirow{3}{*}{$\begin{array}{l}\text { distrib. de } \\
\text { esterco }\end{array}$} & trator+carr. & $3 \mathrm{~h} / \mathrm{l}$ & 15,470 & 41 & 30 \\
\hline & & & & & \\
\hline & & & & & \\
\hline \multirow[t]{2}{*}{ irrigação } & trator+tanque & & 15 & 46 & 30 \\
\hline & & & & & \\
\hline repl & & $30 \mathrm{r}$ & 0 & 20 & 00 \\
\hline & trator + roçad. & & 15 & 34 & 46 \\
\hline capina na linha & & $100 \mathrm{~h}$ & & 94 & 20,00 \\
\hline lanut. de acessos & motoniv. & 1h/ha & 32,231 & 32,23 & $4.190,03$ \\
\hline adub. de cobertura & & $15 \mathrm{~h}$ & 0,940 & 14,10 & ,00 \\
\hline veget do escoadouro & trator+mudas & ho & & 250,00 & $32.500,00$ \\
\hline calcé & & 2 & 16 & & \\
\hline fert.planti & & 45,0 ton/ha & 196,600 & 88,470 & 11. \\
\hline fertil & & $\begin{array}{c}133,32 \text { ton } / h \\
a\end{array}$ & 00 & 27,910 & ,23 \\
\hline esterco de gal. & & 12ton/ha & 40,000 & 480,00 & 62.4 \\
\hline mudas de plantio & & 2222un/ha & 1,075 & $2.388,65$ & $310.524,50$ \\
\hline mudas de replantio & & 222un./ha & 1,075 & 238,86 & $31.051,80$ \\
\hline form & $12 \mathrm{~kg} / \mathrm{ha}$ & $12 \mathrm{~kg} / \mathrm{ha}$ & 2,690 & & $4.196,40$ \\
\hline 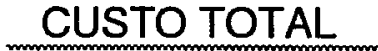 & & & & 0.0 & 10 \\
\hline
\end{tabular}


Como pode se observar, a estimativa do Custo Total de Recuperação da área de empréstimo é relativamente alto, cerca de US\$736 mil. Para esse total estimado o Reafeiçoamentodo do Terreno contribui com 21,051\%, enquanto a Recomposição Vegetal e os Insumos correspondem a 20,85 \% e $58,10 \%$ respectivamente. O item Insumos portanto, é o centro de custos que maior peso tem na estrutura do Projeto. A estimativa feita do Custo do Projeto de Recuperação confrontada com o Custo Total da Barragem do Rio Jundiaí fornecido pelo empreendedor, sendo esse US\$ 43 milhões de dólares, representa $1,7 \%$ do Custo Total da Obra. Portanto dentro deste contexto o custo de recuperação torna-se um valor baixo

\section{2 - Cálculo do Custo de Oportunidade da Utilização de Área de Empréstimo, Sem Posterior Recuperação}

Os benefícios que poderiam ser gerados em uma área natural, tal qual deveria ser o local em estudo, antes da exploração e posterior degradação, são considerados bens intangiveis. As avaliações econômicas tradicionalmente utilizadas para o tipo de exploração feita na área geram valores desprezíveis ou às vezes simplesmente não os consideram, porque o local não possuía nenhuma atividade que gerasse valores econômicos tangiveis anteriormente. Portanto, os recursos ambientais normalmente ou são ignorados ou subavaliados nos processos de decisão. Essas além de contrariar o que está estabelecido pela Constituição Federal, onde o meio ambiente é reconhecido como um bem de uso comum do povo e de interesse de todos, pode gerar diversos problemas no futuro. Isso porque não propicia incentivos ao mercado de sorte a viabilizar o gerenciamento eficiente dos recursos naturais, ocasionando a utilização destes sem critérios e assim comprometendo a sustentabilidade dos ecossistemas.

Considerando a área em estudo onde, após sua utilização como empréstimo não ocorreram trabalhos para recuperação, pode-se perceber claramente que muitos beneficios deixaram de ser gerados. Segundo DIXON (1991), os benefícios intangiveis gerados em áreas naturais protegidas, que 
podem ser extrapolados para áreas naturais que ainda não foram legalmente protegidas, são os seguintes:

- Propriedades geradas pela proteção à bacia: controle da erosão, redução do fluxo local, regularização da vazão dos córregos;

- Processos ecológicos: fixação e circulação de nutrientes $\left(\mathrm{H}_{2} \mathrm{O}, \mathrm{N}_{2}\right.$, $\mathrm{CO}_{2}, \mathrm{O}_{2}$ ) formação de solo, purificação do ar e da água;

- Bens relacionados à biodiversidade: recursos genéticos, proteção de espécies e processos evolutivos;

- valores Educacionais;

- valores Espirituais;

- valores de Pesquisa;

- valores Estéticos;

- Valores culturais e Históricos;

- Valor de opção e de Existência; e

- suporte Global de vida.

Durante o processo de exploração da área, alguns recursos existentes foram retirados (terra, lenha, recursos genéticos.), apesar de não terem sido integralmente aproveitados. Na realidade somente a terra o foi, mesmo assim com desperdício. Como a área permaneceu degradada, inviabilizou-se a produção de novos bens e conseqüentes benefícios, tangiveis e intangíveis. Essa abordagem é feita dentro de um conceito de que os recursos naturais são limitados. Os bens tangiveis (terra, madeira, fauna, flora) haviam sido totalmente destruídos. Os bens intangiveis que se caracterizam pela não exclusividade, não rivalidade e por produzirem efeitos indiretos além de seus limites territoriais possuem grandes dificuldades em sua mensuração. Assim, para mensurar os prejuízos daí derivados, optou-se pela avaliação econômica através de um método indireto - o custo de oportunidade - baseado em 
benefícios que poderiam ter sido gerados se a área em vez de ter permanecido estéril tivesse sido explorada da forma mais rentável possivel: no caso, serão usadas receitas tangíveis para avaliar benefícios intangiveis que foram perdidos.

Como o local em estudo, desde 1976, com a aprovação da Lei Estadual no 893 faz parte da Área de Proteção aos Mananciais da Região Metropolitana de São Paulo, a sua utilização comercial apresenta algumas restrições. $E$, tendo presente que ela também fazia parte de uma várzea, próxima ao rio Jundiaí, considerou-se que a opção alternativa mais rentável e viável para o uso da área seria a agricultura. Devemos lembrar sempre ser essa uma situação artifícial criada para valorar o bem, mas uma situação hipotética.

As observações referentes a utilização do terreno foram feitas a partir dos mapas de capacidade de uso do solo em escala 1: 25.000 do Sistema Cartográfico Metropolitano (S.C.M.). Para estimativa dos valores, foram usados os dados de produção por cultura e o rendimento médio por hectare obtidos da pesquisa Subjetiva. Esta é realizada bimestralmente pelo Instituto de Economia Agrícola de São Paulo (I.E.A.) em diversos municípios, inclusive no de Mogi das Cruzes. Os preços utilizados foram as médias de preços diários recebidos pelos agricultores no ano de 1994 até agosto (mês de referência), de acordo com o banco de dados do I.E.A., deflacionados pelo Índice Geral de Preços (I.G.P.-DI) da Fundação Getúlio Vargas. Os dados de produção agrícola do município foram ordenados pelo tamanho da área ocupada pela atividade e assim escolhidas as principais culturas, com seus rendimentos médios para o município de Mogi das Cruzes.

Multiplicando-se os preços médios corrigidos, pelo rendimento médio por hectare para as culturas do município que ocupavam maior àrea, obtém-se uma série de valores que representam as receitas que poderiam ter sido geradas em um hectare da área degradada, se o uso alternativo escolhido fosse esse. Esses valores foram, então, multiplicados pela área total degradada ( 130ha ) e depois pelo número de anos (20), que a referida área 
permaneceu sem nada produzir. Chegou-se assim ao valor total dos benefícios hipoteticamente gerados para as culturas escolhidas (ver Tabela 3).

Considerando-se ainda que a hipótese de produção de uma monocultura, durante todo ano, por vinte anos, é inviável em termos agronômicos, as estimativas de valor adicionado da cultura de maior receita bruta, o tomate de mesa, foram feitas para oito ciclos de cultivo dentro do período de vinte anos, ou seja dois anos consecutivos de plantio e tres de pousio. Com base nas estimativas de Ueno e Okawa (1992) foi utilizado o valor de US\$4,8mil por hectare como referência para a produção intermediária da cultura selecionada cujo valor foi subtraído da receita total obtida anteriormente. Assim têm-se o valor adicionado pela área. 
Tabela 3- Rendimento e Receita de Culturas no Município de Mogi das Cruzes - SP (valores expressos em US $\$$ de agosto de 1994) ${ }^{(1)}$

\begin{tabular}{|c|c|c|c|c|}
\hline PRODUTO & $\begin{array}{c}\text { Rendiment } \\
0 \\
\text { Físico/ha } \\
\end{array}$ & $\begin{array}{c}\text { Receita/ha } \\
\text { US\$ (ago.94) }\end{array}$ & $\begin{array}{l}\text { Receita Área } \\
\text { Total (130ha) }\end{array}$ & $\begin{array}{l}\text { Receita Total }{ }^{(4,5)} \\
\text { US\$ (20 anos) }\end{array}$ \\
\hline BATATA & $300 \mathrm{sc}$ & $5.864,68$ & $762.408,40$ & $15.248 .168,00$ \\
\hline CEBOLA & $14.000 \mathrm{~kg}$ & $3.507,98$ & $456.037,97$ & $9.120 .759,46$ \\
\hline $\begin{array}{c}\text { FEIJÃO } \\
\text { MANDIOCA }^{(4)}\end{array}$ & $17 \mathrm{sc}$ & 923,83 & $120.098,00$ & $2.01 .960,00$ \\
\hline INDUSTRIAL & 18,4 ton & 557,20 & $72.436,64$ & $724.336,40^{(4)}$ \\
\hline $\begin{array}{c}\text { MANDIOCA } \\
\text { DE MESA }\end{array}$ & $800 \mathrm{cx}$ & $2.151,55$ & 279701,22 & $2.797 .012,20^{(4)}$ \\
\hline $\begin{array}{c}\text { TOMATE DE } \\
\text { MESA }\end{array}$ & $2.500 \mathrm{cx}$ & $21.753,07$ & $2.827 .900,00$ & $56.558 .000,00^{(5)}$ \\
\hline
\end{tabular}

(1) US $\$ 1.00=R \$ 0,898$

(2) Rendimento - média de produtividade, 1991 a 1993

(3) Preço - média de valores reais de janeiro a agosto de 1994

(4)Receita estimada para 10 anos de produção.

(5)Receita estimada para 8 anos de prrodução

Fonte: Instituto de Economia Agrícola - IEA

Optou-se pela utilização do dólar americano, em virtude da estimativa de custo do Projeto de Recuperação também ser apresentada nessa unidade. Isto para que depois as informações possam ser comparáveis entre si em diferentes datas. Como a paridade entre as duas moedas não pode ser garantida, a conversão dos dados foi feita com base no valor do dólar de agosto.de 1994 (R $\$ 0,898=$ US\$1.00); dados obtidos da Revista Conjuntura Econômica, vol 48, n $011,1994$.

Cabe frisar mais uma vez que alguns beneficios perdidos - valores espirituais, estéticos, culturais, históricos, de existência, de opção - não puderam ser estimados por essa metodologia, mas apesar disso não devem ser esquecidas no final dos processos decisórios. 
Os resultados compreendem as estimativas, do CUSTO DO PROJETO DE RECUPERAÇĀO DA ÁREA DEGRADADA em torno de US \$ 736 mil e, o CUSTO DE OPORTUNIDADE do melhor uso alternativo, qual seja, o valor adicionado pela cultura do tomate de mesa, cujo valor estimado está em torno de US\$17,6 milhões. Esta valoração é obtida subtraindo da receita bruta por hectare (US\$ $21.753,07)$ a "produção intermediária"(US\$ 4.800). Esta do modo que é conceituada nas contas nacionais, em macroeconomia. Isso equivale a se obter um valor adicionado, no caso, benefício perdido de US\$16.953,07 por hectare no ciclo produtivo, ou ainda US\$2.203.899,10 pelos 130 hectares da área de empréstimo em cada um dos anos de produção. Ou seja, US\$ 17.631.192,80 nos oito ciclos considerados. Em termos ideais, também deveriam ser incluidos os VALORES AMBIENTAIS QUALITATIVOS, não mensurados monetariamente. Tais valores compreenderiam o valor monetário estimado, ou mais precisamente a ordem de grandeza do dano imposto à sociedade pelo uso dos recursos naturais da área de empréstimo, para a construção do maciço da Barragem do Rio Jundiai, sem que ocorresse a posterior recuperação desta. 


\section{6 - CONCLUSÕES}

As soluções para os problemas ambientais, em geral, e principalmente para aqueles considerados globais, que atingem a toda humanidade, representam alguns dos principais desafios neste fim de século. Neste cenário, têm-se tentado obter em Fóruns Globais, algumas resoluções que deveriam ser obedecidas pelos diversos países signatários dos acordos firmados. Isso é importante, uma vez que, na maioria dos casos, as soluções só serão efetivas se tomadas globalmente. Isso também ocorreu, na Conferência das Nações Unidas sobre o Meio Ambiente, a ECO-92, onde depois de muitos encontros preparatórios foram produzidos e assinados vários documentos: a Declaração do Rio ou Carta da Terra, a Agenda 21, a Convenção do Clima e a Convenção da Biodiversidade.

A despeito do grande número de países signatários dos acordos internacionais, a realidade é que os resultados ainda se mostram incipientes. Um dos fatores que explicam a debilidade desses acordos é que os interesses de curto prazo são diferentes, afora, é claro, as dificuldades inerentes à implantação das resoluções teoricamente pré-acordadas. Depreende-se então 
que essa forma de atuação democrática, embora aparentemente correta, na prática apresenta resultados insatisfatórios.

Em função dessas constatações, um considerável esforço também deve ser feito em análises e intervenções de caráter microeconômico, de forma a integrar ações que concorram para o desenvolvimento sustentável. Isso porque os processos produtivos têm efeitos que podem ser maléficos ou benéficos a indivíduos e gerações. $E$ tais prejuízos ou benefícios não são ressarcidos, nem auferidos. Logo, a abordagem microeconômica, ao sinalizar aos múltiplos agentes dos processos econômicos, os reais custos de suas operações, tem um espaço importante a ocupar na gestão ambiental.

Através da revisão das técnicas de valoração ambiental conhecidas, feita no Capítulo 2, conclui-se que, cada caso deve ser muito bem avaliado, desde o fenômeno ocorrido e seus efeitos indiretos até os dados a serem obtidos e sua qualidade, para então escolher-se a melhor técnica a ser aplicada. Com técnicas baseadas na teoria econômica, somadas aos conhecimentos ecológicos, podem-se desenvolver metodologias práticas para se avaliar determinado tipo de dano ambiental. Mas a metodologia desenvolvida não deve ser extrapolada para qualquer caso, porque o tipo de processo ambiental (sobretudo seus efeitos), é diferente em cada caso.

O desenvolvimento dessas metodologias é muito importante, uma vez que, no caso de avaliação econômica ambiental, é necessário possuir conhecimentos em áreas muito distintas, como ecologia e economia, os quais um especialista normalmente não possui. Portanto, torna-se urgente o desenvolvimento de metodologias que auxiliarão a resolver os processos ambientais que venham prescindir de pericias. Pode-se citar o caso da Companhia de Tecnologia de Saneamento Ambiental do Estado de São Paulo CETESB, que desenvolveu uma metodologia para avaliar um tipo de dano específico, causado por derramamento de petróleo no mar.

Neste trabalho, utilizou-se o instrumental econômico para se fazer uma avaliação dos recursos naturais perdidos devido à uma intervenção antrópica. A diferença assinalada com relação aos trabalhos convencionais de análise econômica está na importância que se dá ao valor dos recursos naturais e a 
sua possibilidade de exaustão. Por exemplo, a terra enquanto recurso natural e não apenas insumo produtivo, é considerada recurso finito e escasso, e por isso mesmo, deve ter um valor monetário, além daquele usualmente atribuído pelo mercado imobiliário. No presente estudo de caso, isso foi particularmente verdadeiro pois mais do que exploração de área de "empréstimo", o que se assistiu foi eliminação da terra como recurso produtivo. Ocorreu, de fato, uma PERDA DO AMBIENTE já que o terreno ficou totalmente improdutivo. Este caso demonstra a necessidade de retomar-se os estudos sobre valor da terra.

Isso posto, calculou-se, além do Custo de Reposição da dinâmica do ecossistema local (que naturalmente não é equivalente à dinâmica de um ecossistema primário, mas a um padrão ecologicamente aceitável), alterado pela exploração da área de empréstimo, o Custo dos Benefícios Perdidos, recorrendo-se para isso à técnica do custo de oportunidade. Por esta via devese escolher o valor da produção que haveria em seu melhor uso alternativo. Decidiu-se pela maior receita que poderia ter sido gerada naquela terra, considerando-se os produtos agrícolas da região, e lembrando que a produção agrícola seria a mais adequada face aos benefícios que a área poderia fornecer e que foram perdidos. Deve-se reter, porém, que tal maneira indireta de se avaliar não pode esquecer que os benefícios gerados pelo ambiente natural são sempre maiores do que aqueles que poderiam ser extraidos diretamente da produção de bens que passam pelo mercado, visto que existem funções e valores que não são objeto das trocas na economia. Ou seja, calculando-se esse valor baseado em bens que passam pelo mercado, o valor obtido será somente uma estimativa, mas segundo o método dos benefícios perdidos, ele pode ser equiparado ao valor dos recursos que existiam na área, desde que acrescidos dos valores qualitativos que são mais difícéis de se mensurar. Assim, os valores obtidos da ordem de US\$736 mil para a Recuperação e US $\$ 17,6$ milhões para o Custo de Oportunidade não podem ser desprezados. $\mathrm{O}$ fato de se ter um intervalo muito grande entre as diferentes culturas utilizadas, serve para alertar o cuidado e que deve ter com a aplicação desta metodologia

Uma crítica para a presente análise é que ela aborda apenas um só dos impactos provocados pela barragem, sendo assim a mensuração do dano 
resultante deste procedimento pode ter um resultado limitado. No caso estudado seria mais recomendável que fosse feito o tratamento da barragem e de seus impactos como um todo. Os efeitos totais provocados pela construção e também os benefícios gerados por esta, tal como o fornecimento de água para a população, poderiam ter sido internalizados. A envergadura de uma proposta com esse escopo, contudo, extrapolaria os objetivos do presente trabalho.

É necessário notar, também, que o fato dos recursos já terem sido degradados restringiu o leque de alternativas metodológicas para a avaliação. Todavia, se por um lado isso realmente limitou a possibilidade de se utilizar outras técnicas, por outro há de se reconhecer que simplificou e o processo de obtenção dos dados. Considera-se, assim, que a técnica pode ser considerada, em sua essência, um estudo econômico preliminar que poderá servir de orientação para a realização futura de estudos mais abrangentes.

Outra limitação que se mantém insolúvel é a dificuldade em afirmar qual a efetiva possibilidade de recuperação da área. Sem embargo, cada área degradada deve ser tratada individualmente, não existindo base na literatura para se afirmar os prazos ou mesmo o tempo necessário para a recuperação. Portanto, preferiu-se correr algum risco e fazer a previsão dos custos de um projeto de recuperação como se ele fosse ocorrer normalmente. As conclusões sobre o mérito desse trabalho só poderiam ser tiradas depois de um longo período e desde que ocorresse, de fato, a implantação do projeto de recuperação. A melhor estratégia seria talvez a realização de um projeto em uma pequena área como experiência; um autêntico "projeto piloto" para se saber a viabilidade da recuperação antes de executá-lo integralmente, arcando com todos os custos.

Conquanto todos os óbices assinalados para a avaliação econômica dos recursos naturais, a mensagem central é que os setores público e privado não terão alternativas, salvo o aperfeiçoamento do instrumental analítico para tratamento da questão ambiental. Para corroborar essa afirmação, basta citar as inúmeras ações de dano ambiental pendentes no sistema judiciário. Se elas tiverem prosseguimento poderão tanto atingir a imagem quanto a pressuposta 
lucratividade das empresas públicas e privadas no que tange aos investimentos em recuperação ambiental.

Conclui-se, por fim, que a avaliação de projetos convencional necessita urgentemente incluir a variável ambiental. Para isso os recursos naturais precisam ser valorados monetariamente. Somente assim a sociedade poderá deter possibilidades de realizar escolhas no presente sem comprometimento, ao menos em demasia, do bem estar das gerações futuras. 


\section{BIBLIOGRAFIA:}

ANDERSON, D.,The Economics of Afforestation - A Case Study in Africa. The World Bank Occasional Paper $N^{\circ} 1 /$ New Series (Baltimore, M. D: The John Hopkins University Press, 1987).

BERTONI, J. \& LOMBARDI NETO, F. Conservação do solo. São Paulo, Ícone, 1990, 355p.

CHIOSSI, N.J. Geologia Aplicada à Engenharia. São Paulo, Grêmio Politécnico, Poli-USP, 1975.

CHIOSSI, N.J. Ocupação do solo e impacto ambiental. Revista Brasileira de Tecnologia, Brasília, v.13 (5), out./nov, 1982, p.44-51.

CESP - Companhia Energética do Estado de São Paulo. Recuperação de áreas degradadas; Série Pesquisa e Desenvolvimento, $\mathrm{n}^{\circ} 59,2^{\mathrm{a}}$ ed., São Paulo, 1992, 15p. 
CONSTANZA, R. What's ecological economics? Ecological Economics 1: 1989.

CONSTANZA, R. Economia Ecológica: Uma agenda de pesquisa. In: May, P.\& R. Serôa da Motta (orgs.) Valorando a Natureza: Análise Econômica para o Desenvolvimento Sustentável. Rio de Janeiro, Editora Campus, 1994.

DIXON, J.A.(ed.) Economic valuation technique for the enviromnent: a case study workbook. Baltimore, EastWestCenter, 1990, 203p.

DIXON, J.A.\& SHERMAN, P.P. Economics of Protect Areas: A New Look at Benefits and costs, London, Earths Can, 1991, 334p.

FELDMAN, F. (coord.) Guia da Ecologia. São Paulo, Ed. Abril, 1992, 319p.

FONSECA, E.G. da Comportamento Individual: Alternativas ao Homem Econômico. Estudos Econômicos, São Paulo v.20, № ESPECIAL, 1990, pp.5-37.

FREITAS, V.P. de Direito administrativo e meio ambiente. Curitiba: Juruá, 1993, 128p.

GOVERNO DO ESTADO DE SÃO PAULO. Secretaria de Serviços e Obras Públicas, D.A.E.E.. Sistema Biritiba-Jundiaí, Relatório Final. São Paulo, 1975, abr.

GOVERNO DO ESTADO DE SÃO PAULO. Secretaria de Energia e Saneamento. Environmental Sanitation Program Guarapiranga Water Basin. São Paulo, Maio, 1992. COBRAPE (Companhia Brasileira de Empreendimentos e Projetos).

GRAZIANO NETO, F. Questão Agrária e Ecologia - Crítica da moderna agricultura. São Paulo, Editora Brasiliense; 1982, 154p.

GUILLAUME, M \& ATTALI, J. A Microeconomia: Outro Planeta. In: $A$ Antieconomia. Rio de Janeiro, Zahar, 1975. 
HITZHUSEN, F.J. Global land degradation and national security. Oklahoma City, Soil Conservation Society Annual Meeting, 1984.

HUFSCHMIDT, MAYNARD M.(coord.); Environment, Natural Systems and Development, United States of America; The Johns Hopkins University Press Baltimore and London; 1983; 338p.

IAP/GTZ Impactos do setor hidroenergético em um contexto regional: Avaliação e propostas metodológicas. Curitiba; 1993; 117p.

IAP/GTZ Cenários sobre planejamento e atuação sócio-ambiental do setor hidrelétrico brasileiro. Curitiba, 1993a, 75p.

JACOBS, M. The Green Economy Environment Sustainable Development and and politcs of the future. London, Pluto Press, 1991, 312p.

MAY, P.H. Ecological Economics for Equitable Development, a strategy for Brazil, concept paper prepared for The Rockefeller Foundation Global Environment Program. Rio de Janeiro, 1993, february.

MAY, P.H. \& MOTTA, R. S. (org.) Valorando a natureza: análise econômica para o desenvolvimento sustentável. Rio de Janeiro, Editora Campus, 1994, 195p.

MCNEELY, J.A; MILLER, K.R.; REID, W.V. Conserving the world's biological diversity. Washington, World Bank, 1992, 193p.

MARGULIS, S.A. Economia e o desenvolvimento sustentado.In: Análise Ambiental: uma visão multidisciplinar; Sâmia Maria Tauk, Nivar Gobbi, Harold Gordon Fowler. São Paulo, Ed. Universidade Estadual Paulista, FAPESP: SRT: FUNDUNESP, 1991, 169p.

MARGULIS, S.(ed.) Meio Ambiente: aspectos técnicos e econômicos. Rio de Janeiro, IPEA/PNUD, 1990, 246p.

MENCK, P.C.M. Avaliação Econômica do controle da erosão na microbacia do Ribeirão Iperó, em Araçoiaba da Serra, Estado de São Paulo. Piracicaba, 
1993, 181p. (Mestrado-Escola Superior de Agricultura "Luiz de Queiroz"/USP).

MUNASINGHE, M.. Environmental Economics and Natural Resources Management in Developing Countries. Washington, D. C.: Committe of Internacional Development Institutions of the Environment (CIDIE), 1993

MUNASINGHE,M.. Environment Issues and Economics Decisions in Developing Countries. World Development, Grã- Bretanha, v.21, no 11, 1993, p.1729-1748.

MONTOYA, L.J. \& SORRENSON, W.J. Implicações econômicas da erosão do solo e das práticas conservacionistas no Paraná. Londrina, IAPAR, 1984, $146 \mathrm{p}$.

MUSGRAVE, R. \& MUSGRAVE, P. .Finanças Públicas. São Paulo, Ed. Campus/ EDUSP, 1980.

PEARCE, D.W. \& TURNER, R.K. Economics of natural resources and the environmental. Baltimore, Maryland, Johns Hopkins. University Press, 1989, 373p.

PEARCE, D.W. \& ANIL MARKANDYA Environmental Policy Benefits: Monetary Valuation, OECD, Paris, 1989.

PESKIN, H.M. Accounting for natural resource depletion and degradation in developing countries. The World Bank, Enviromnent Working Paper n.13, 1989, January.

RAlJ, B. Van Recomendações de adubação e calagem para o Estado de São Paulo. Campinas, Instituto Agronômico, 1985, 107p.(Boletim Técnico, 100)

RANDALL, A. Resource Economics, An Economic Approach to Natural Resource and Environmental Police. Columbus, Ohio, Grid Publishing, 1987, 424p.

SÁNCHEZ, L.E. Avaliação do impacto ambiental na mineração. Brasil Mineral 48:116-121. 
SÁNCHEZ, L.E Avaliação do impacto ambiental na mineração: interações entre o projeto técnico e os estudos ambientais. Simpósio EPUSP sobre Controle Ambiental e Segurança na Mineração, pp.23-37.Escola Politécnica da Universidade de São Paulo.

SERÔA DA MOTTA, R. Análise de custo-benefício do meio Ambiente.In: Meio Ambiente: aspectos técnicos e econômicos. Rio de Janeiro, IPEA: Brasília, IPEA/PNUD, 1990, 246p.

S.E.S.C. SERVIÇO SOCIAL DO COMÉRCIO. Ecologia: Qualidade de Vida. São Paulo;1993;125p.

SILVA, J.R.C. Perdas de solo e produção de sedimentos - Estimativas em uma pequena Bacia Hidrográfica localizada em Piracicaba-SP. Piracicaba, 1978, 61p. (Mestrado-Escola Superior de Agricultura "Luiz de Queiroz"/USP)

SIMON, C \& R. DEFREYES. Uma Terra, Um Futuro.Ed. Macron, 1992, $1^{\text {a. }}$ ed. , $179 p$.

SOUTHGATE, D.; HITZHUSEN, F.; MAcGREGOR, R. Remeding Third World Soil Erosion Problems. American Journal Agricultural Economics, 66(5): 879-884, 1984.

UENO, L H .\& OKAWA, H..Custos de produção e preços no mercado de tomate de mesa, 1986-91.. Agricultura em São Paulo,S.P.39(1):179-93, 1992.

U.N. C E.D.. Comissão Mundial para o Meio Ambiente e Desenvolvimento. Nosso Futuro Comum.Rio de Janeiro, Ed. Fundação Getúlio Vargas , $1991,2^{\mathrm{R} e d,} 430 \mathrm{p}$.

VEIGA, J.E.da. Sobre o Enigma da Renda. In: Estudos Econômicos, São Paulo,.20(3),461-477, set-dez/1990.

VEIGA, J.E.da. Contabilidade Ambiental. In: Intercâmbio, SESC-Rio de Janeiro, 5(13): p.73-81, 1992. 
VINCENT, J.R.(ed.) Valuing environmemt benefits in developing Economies. East -Lansing, Michigan State University, 1991, 199p.tab.graf. "Proceeding of a Seminar series held feb.-may, 1990 at Michigan State University".

VIOLA, E. J. O Movimento Ambientalista no Brasil (1971-1991): da denúncia e conscientização pública para a institucionalização e o desenvolvimento sustentável. In: Ciências Sociais Hoje. Anpocs, Rio de Janeiro, Vértice, 1992.

ZULUAUF, W. E.. A ldeologia Verde e outros ensaios sobre o meio ambiente. São Paulo, Geração Editorial,1995. $1^{\circ}$ ed. 354 p. 


\section{APÊNDICE: FIGURAS}

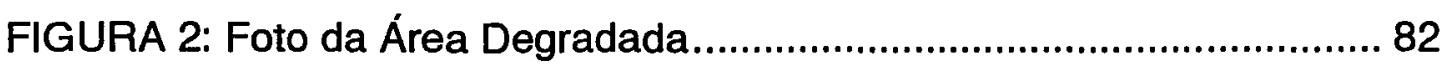

FIGURA 3: Divisão Hidrográfica do Estado de São Paulo ......................... 84

FIGURA 4: Sistemas Produtores de Água da RMSP em 1986................... 86

FIGURA 4a: Evolução dos Sistemas Produtores de Água da RMSP

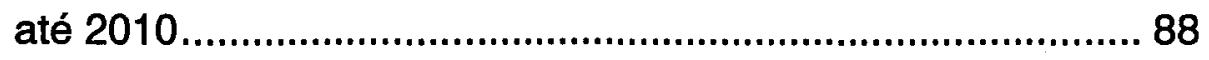

FIGURA 5: Represa do Rio Jundiaí, vista pelo satélite LANDSAT ............. 90

FIGURA 6: Barragem de Concreto do Rio Jundiaí - Seções Principais ...... 92

FIGURA 7: Índice Pluviométrico da Barragem do Rio Jundiaí .................... 94 


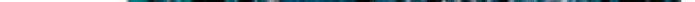


FIGURA 3: Divisão Hidrográfica do Estado de São Paulo 


\section{Primeiro Grupo}

20 iguapei

21 pisic

22 Pontal do Parmapanema

Wegundo Grupo

14 : Also lamanapansm?

17 Mćdo Paramananema

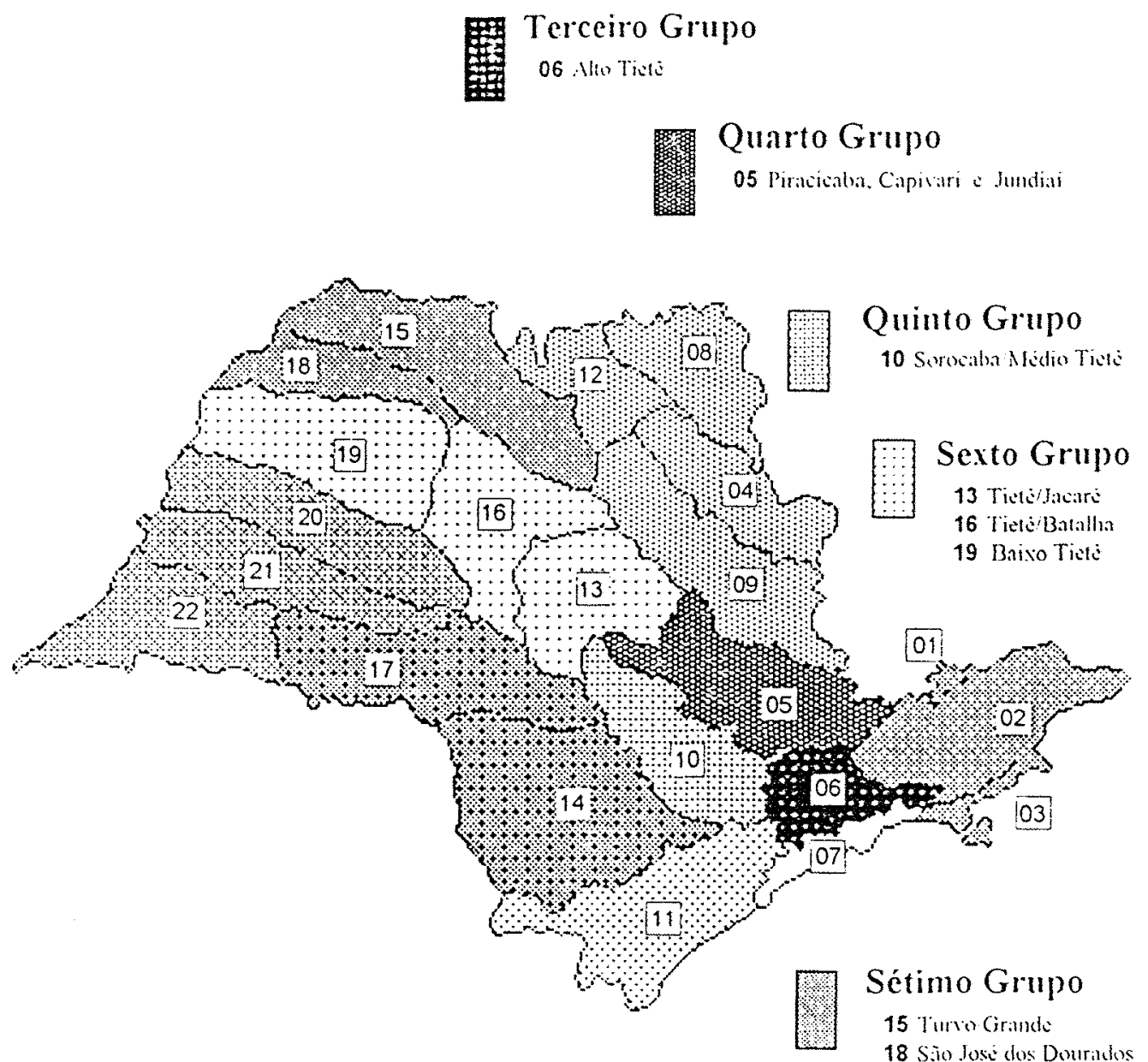

\section{Oitavo Grupo}

04 Pirrdo

08 Sipucil Grands

09 Mogi-Cinaly

12 Barivo l'ardocinato

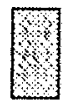

\section{Nono Grupo}

01 Nambunar:

02 Paraibra do Sul

03 Lilomal Norti

\section{Décimo Grupo}

11 Ribura do Igualpe Litomal Sul

\section{Décimo Primeiro Grupo}


FIGURA 4: Sistemas produtores de água da RMSP EM 1986 

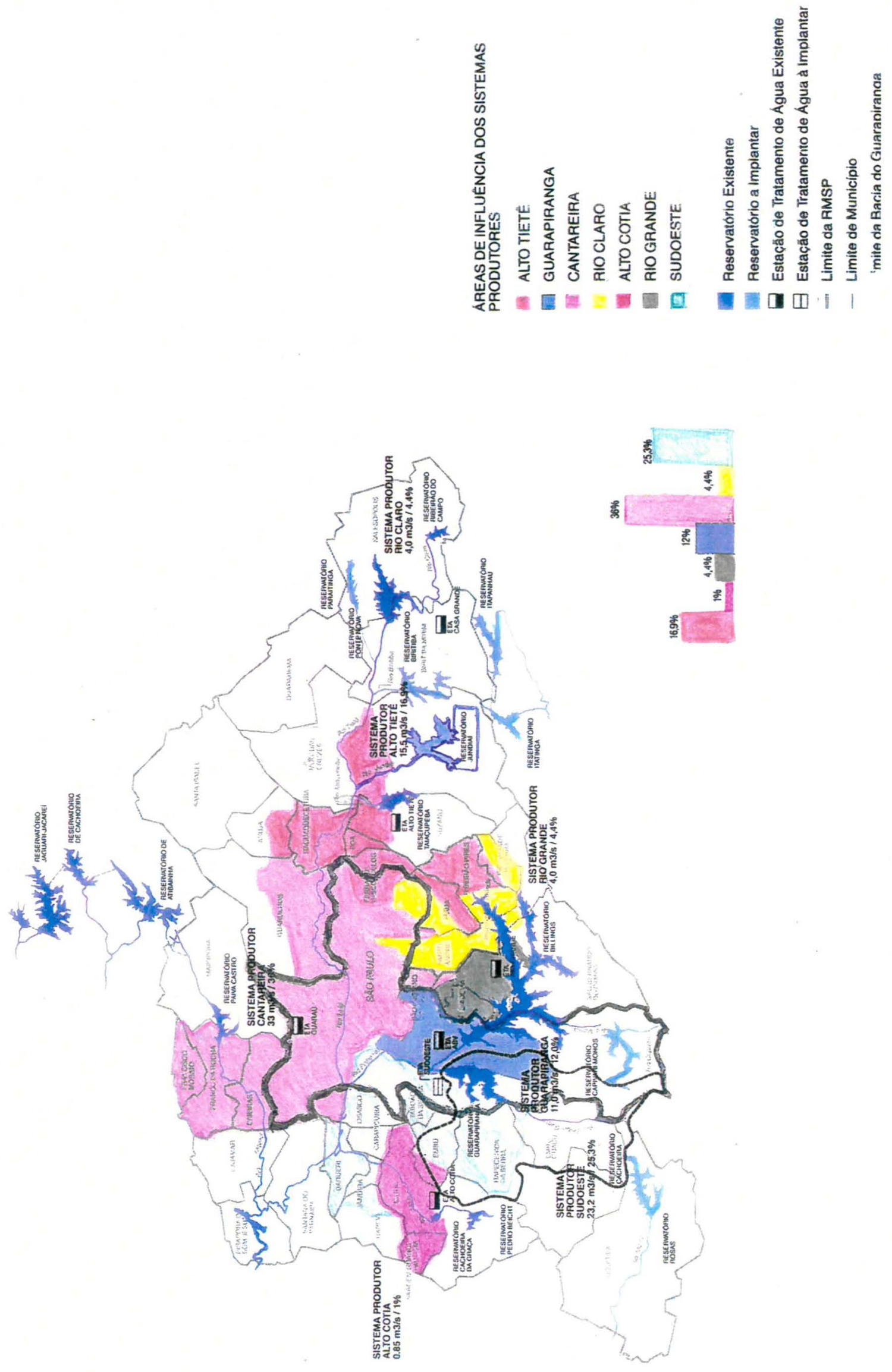
FIGURA 4a: Evolução dos Sistemas Produtores de água da RMSP até 2010 


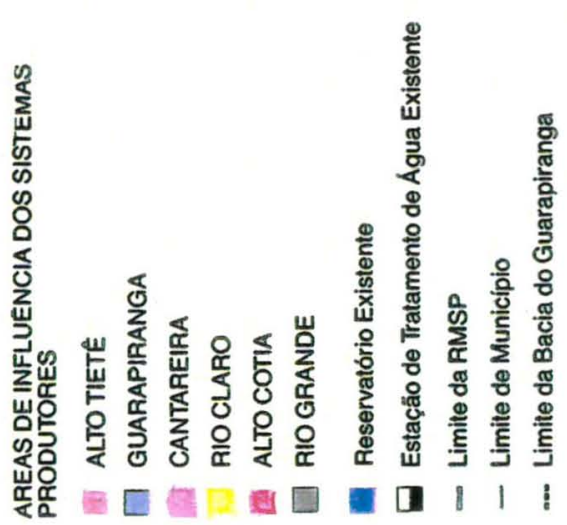

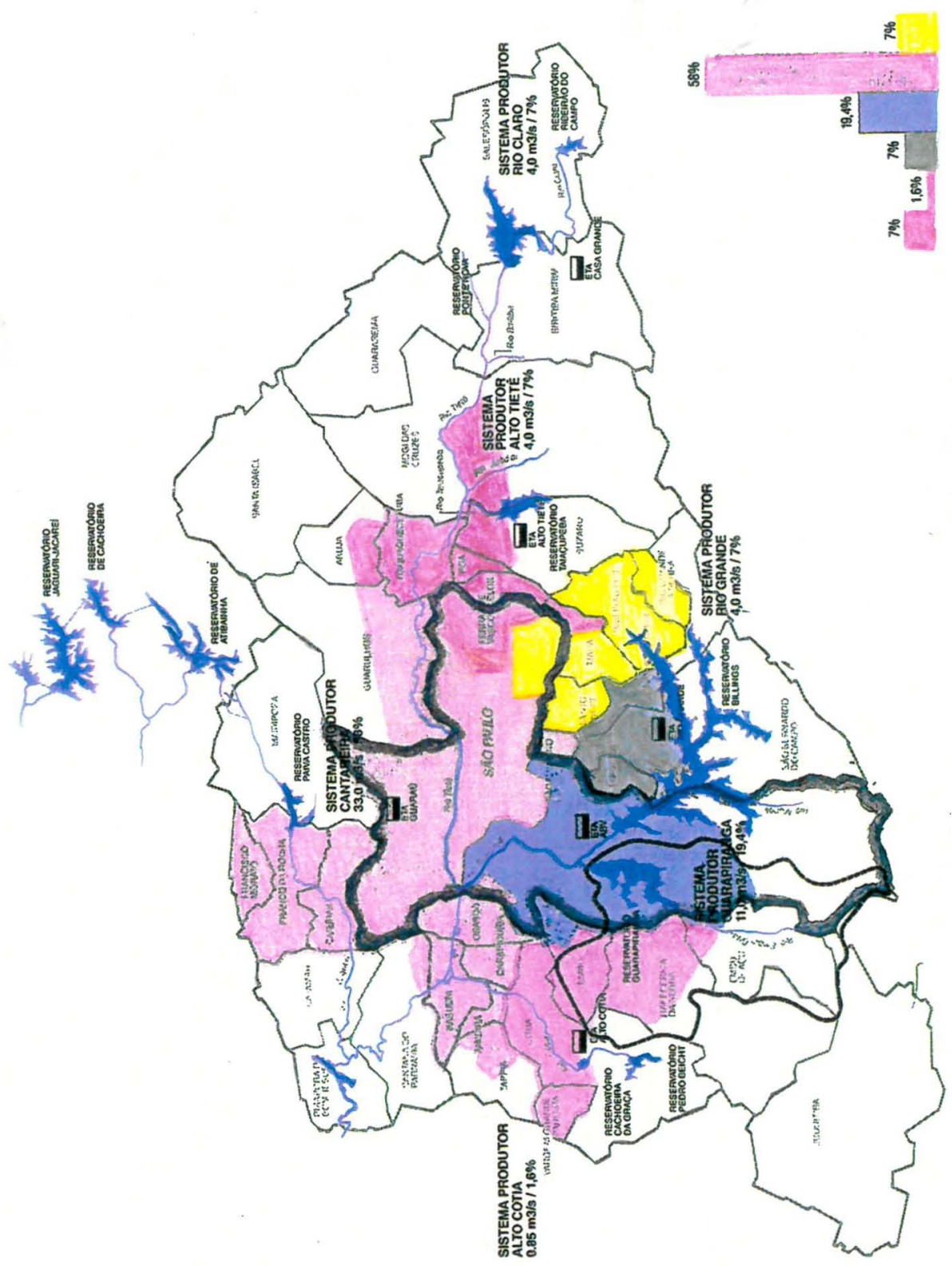


FIGURA 5: Represa do Rio Jundiaí, vista pelo satélite LANDSAT 


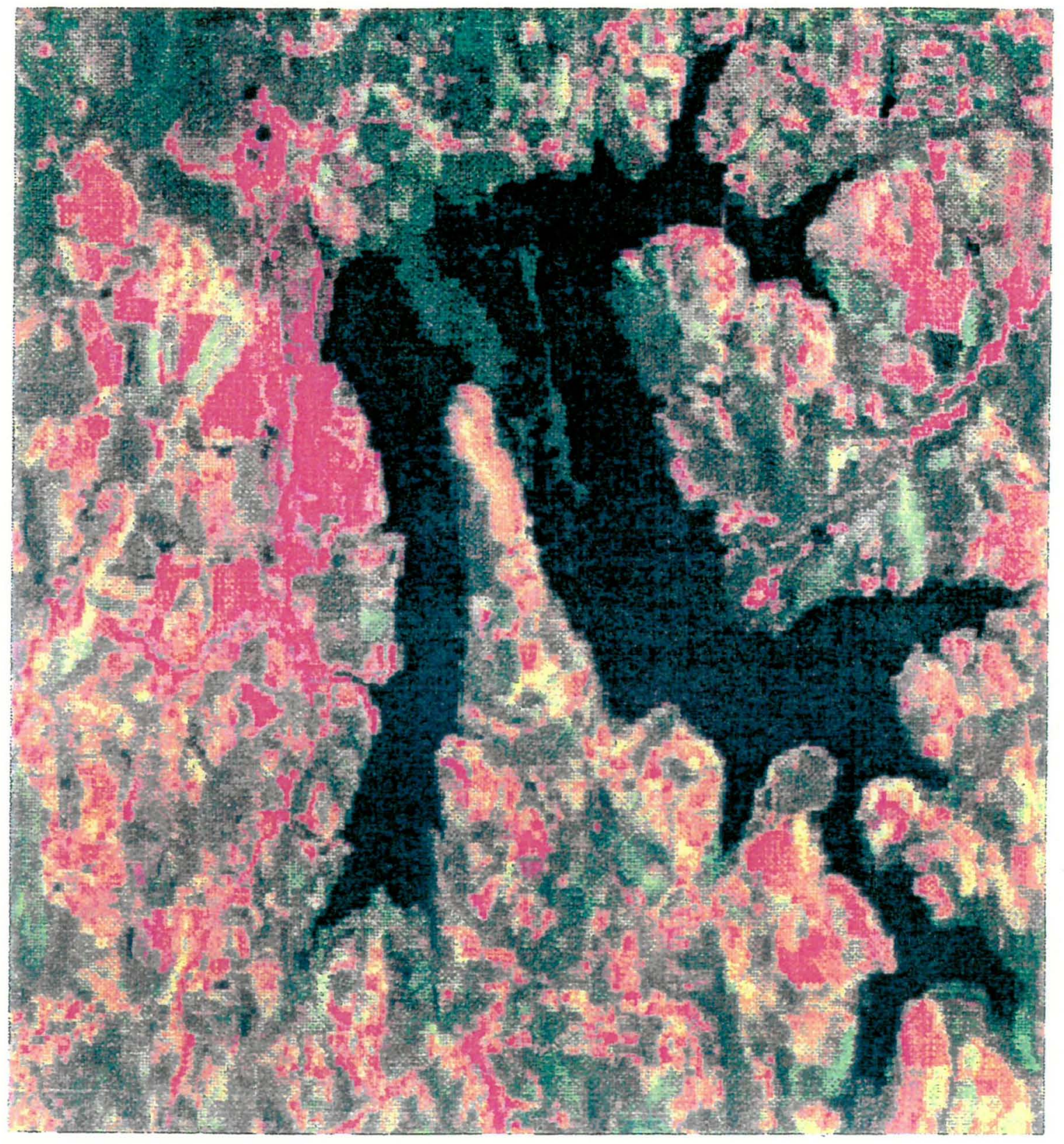


FIGURA 6: Barragem de Concreto do Rio Jundiaí - Seções Principais 

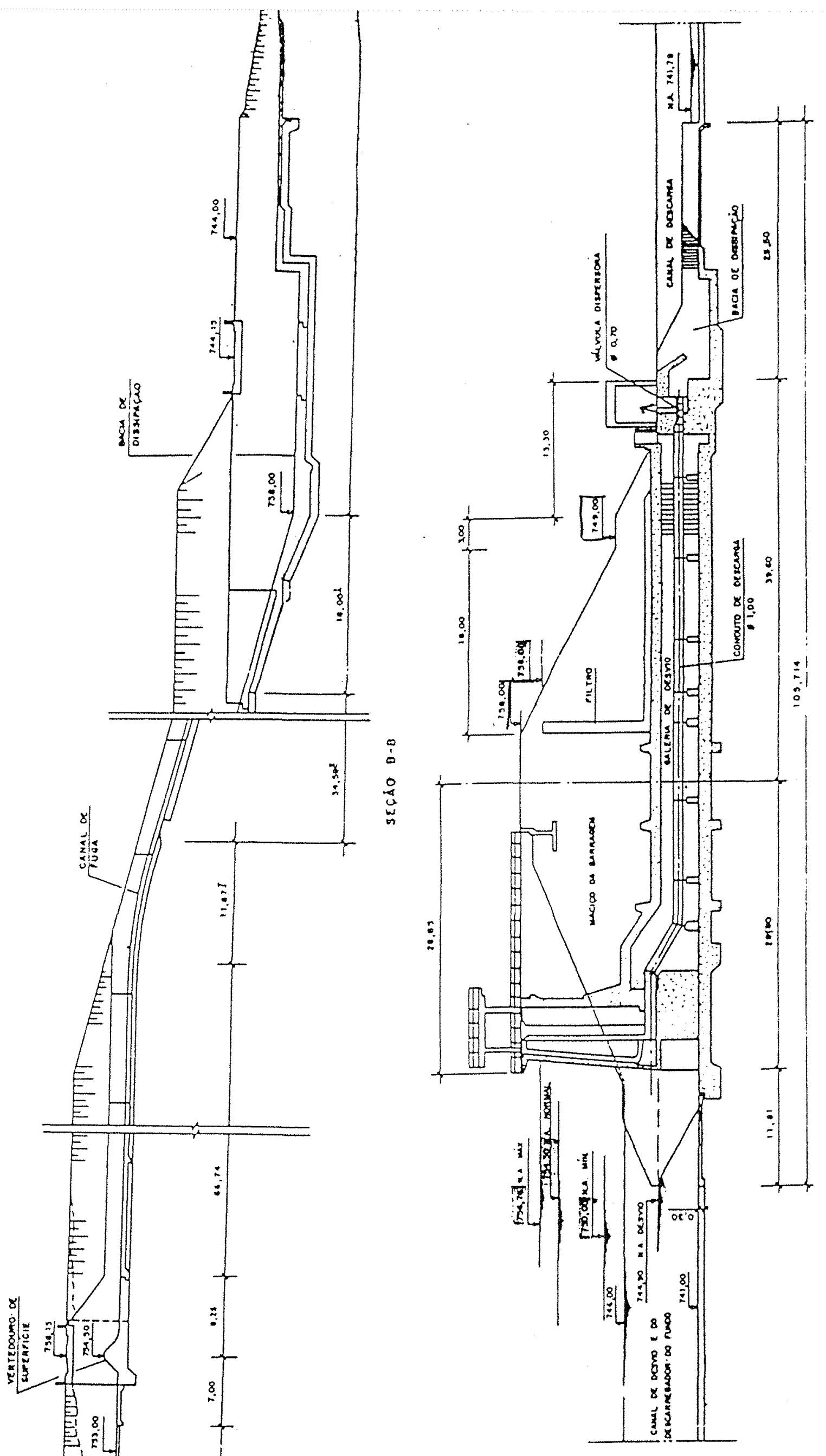
FIGURA 7: Índice Pluviométrico da Barragem do Rio Jundiaí 

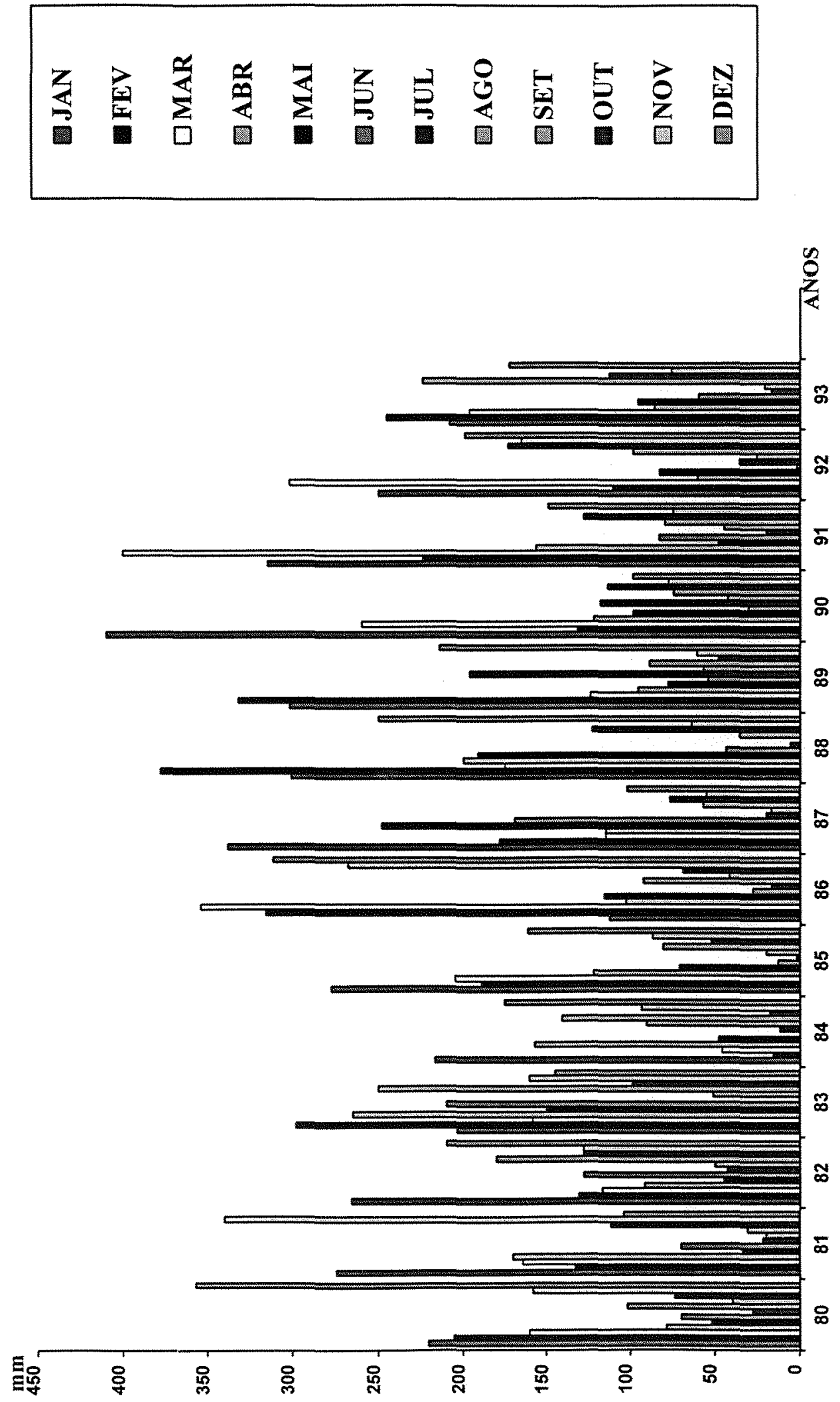